\title{
Permainan Edukasi Operasi Hitung Matematika Berbasis Multimedia pada SD STRADA VAN LITH II
}

\author{
Natalia Ceria ${ }^{1)}$, Hadi Sutopo ${ }^{2)}$ \\ Sistem Informasi, Fakultas Industri Kreatif Kalbis Institute \\ Jalan Pulo Mas Selatan Kav. 22, Jakarta 13210 \\ 1)Email:nataliaceria2@gmail.com \\ 2)Email: hadi.sutopo@kalbis.ac.id
}

\begin{abstract}
SD Strada Van Lith II is an elementary school that the early establishment of Strada society since 1924, and has branches in central Jakarta, tangerang, bekasi and east jakata. SD Strada Van Lith II is a branch of east jakarta, duren palm. The problems that occur are like using whiteboards, markers, guidebooks and others so that this study aims to provide a more enjoyable learning atmosphere in the game world, especially games that are educative. The purpose of the study is to facilitate learning and produce instructional media-based educational game in the form of software on mathematics subjects that can be used as an alternative media to play while learning. The research method used in this research is Multimedia Development Life Cycle (MDLC). The results of this study are desktop-based applications, that this application can provide new solutions in terms of teaching and learning activities and provide positive feedback for SD Strada Van Lith II.
\end{abstract}

Keywords: aplication, game, education, $M D L C$, desktop

\begin{abstract}
Abstrak: SD Strada Van Lith II merupakan sekolah dasar yang awal berdirinya perkumpulan Strada sejak tahun 1924, dan mempunyai cabang di Jakarta pusat, tangerang, bekasi dan jakata timur. SD Strada Van Lith II merupakan cabang dari jakarta timur, duren sawit. Permasalahan yang terjadi adalah seperti menggunakan papan tulis, spidol, buku panduan dan lainnya sehingga penelitian ini bertujuan untuk memberikan suasana belajar menjadi lebih menyenangkan dalam dunia permainan, khususnya permainan yang bersifat edukatif. Tujuan dalam penelitian adalah untuk mempermudah pembelajaran dan menghasilkan media pembelajaran berbasis permainan edukasi yang berbentuk software pada mata pelajaran matematika yang dapat digunakan sebagai media alternatif untuk bermain sambil belajar. Metode penelitian yang digunakan dalam penelitian ini adalah Multimedia Development Life Cycle (MDLC). Hasil penelitian ini adalah aplikasi berbasis dekstop, bahwa aplikasi ini dapat memberikan solusi baru dalam hal kegiatan belajar mengajar dan memberikan danpak positif bagi SD Strada Van Lith II.
\end{abstract}

Kata kunci: aplikasi, permainan, edukasi, MDLC, desktop

\section{PENDAHULUAN}

Matematika merupakan salah satu ilmu pengetahuan yang dianggap rumit dan sulit dipahami pada siswa. Kurangnya keinginan siswa untuk mempelajari matematika dikarenakan adanya rumus-rumus dan lambang-lambang matematika yang sangat rumit sehingga membuat siswa menjadi takut dalam mempelajari matematika. Matematika juga mempunyai peranan penting karena dengan belajar matematika secara benar, daya nalar siswa dapat terolah meski tidak semua tetapi banyak diantara siswa sekolah yang mengeluhkan mata pelajaran matematika. Berdasarkan hasil wawancara yang dilakukan peneliti bahwa siswa berpikir mata pelajaran matematika sulit dan kurang menarik. Untuk itu diperlu pengembangan media pembelajaran agar dapat mengikuti perkembangan jaman. SD Strada Van Lith II adalah sebuah sekolah dasar yang proses penyampaian mata pelajaran masih menggunakan papan tulis, spidol dan menggunakan buku panduan yaitu buku pelajaran. Hal ini membuat kegiatan proses belajar mengajar menjadi membosankan dan pembelajaran tidak diserap dengan baik bagi para siswa dan membuat siswa yang rata-rata memiliki usia 6 sampai dengan 8 tahun pada SD Strada Van Lith menyatakan bahwa siswa kelas 1 dan kelas 2 kurang tertarik dalam belajar, serta siswa yang masih memasuki masa transisi. Transisi adalah sebuah pergantian yang ditandai dari perubahan fase awal ke 
fase yang baru seperti taman kanak-kanak kesekolah dasar yang aktivitas belajarnya dapat dilakukan sambil bermain sampai ke jenjang sekolah dasar yang lebih formal.

Pembelajaran matematika sangat penting bagi siswa sekolah dasar, banyak faktor yang menyebabkan matematika di anggap pelajaran sulit di antaranya adalah karakteristik materi matematika yang bersifat abstrak, logis, sistematis, penuh dengan lambanglambang, dan rumus yang membingungkan. Oleh karena itu, peneliti ingin memberikan sebuah media pembelajaran merupakan alat metode dan teknik yang digunakan dalam rangka lebih mengefektifkan komunikasi dan interaksi antara guru dan siswa dalam proses pendidikan dan pembelajaran di sekolah [1]. Dan disenangi oleh siswa sekolah dasar, serta dengan adanya manfaat media pembelajaran tersebut dapat menarik perhatian siswa selama proses belajar mengajar berlangsung, materi pembelajaran akan dapat lebih mudah dipahami atau lebih mudah ditangkap oleh siswa, membuat siswa lebih aktif dan kreatif dalam belajar, dan siswa dapat mengetahui dengan jelas standar kompetensi dan indikator pembelajaran, sehingga peneliti ingin merancang sebuah game edukasi [2].

Game edukasi digunakan untuk menjadikan proses belajar mengajar menjadi lebih menyenangkan dan memberikan solusi serta berpengaruh positif bagi siswa yang bermain game terutama game dengan konsep manajemen, strategi, ataupun tekateki dapat memberikan pengaruh yang baik terhadap perkembangan otak anak [3]. Dengan semakin berkembangannya dunia teknologi multimedia kini dapat merubah cara siswa untuk belajar, maupun memberikan pengalaman dalam bidang komunikasi seperti pendidikan, teks, grafik, animasi, audio dan video.

Multimedia kini telah mengembangkan proses pengajaran yang lebih interaktif, sehingga pemahaman tentang menggunakan teknologi tersebut dapat lebih efektif dan dapat menghasilkan ide-ide untuk pengajaran dan pembelajaran matematika. Dengan latar belakang tersebut, peneliti ingin membangun sebuah Permainan Edukasi Operasi Hitung Matematika berbasis Multimedia pada SD Strada Van Lith II. Permainan edukasi berbasis multimedia ini diharapkan dapat membantu siswa dalam mempelajari mata pelajaran Matematika (penghitungan) dengan lebih menyenangkan, serta dapat membantu perkembangan otak siswa-siswi SD Strada Van Lith II khususnya dalam memahami pelajaran matematika.
Dari latar belakang di atas maka dapat didapat rumusanmasalahsebagaiberikut:bagaimanamembuat aplikasi Permainan (game) Edukasi Operasi Hitung Matematika Berbasis Multimedia Pada SD Strada Van Lith II, yang dapat digunakan sebagai bagian dalam pembelajaran sehingga permainan tersebut membuat proses belajar mengajar lebih menarik, focus dan menyenangkan. Serta dengan tujuan yang dilakukan peneliti yaitu untuk menghasilkan media pembelajaran berbasis permainan edukasi yang berbentuk software pada mata pelajaran matematika yang dapat digunakan sebagai media alternatif untuk bermain sambil belajar siswa siswa di SD Strada Van Lith II.

\section{METODE PENELITIAN}

Berikut ini merupakan metode penelitian yang dilakukan oleh peneliti dalam membangun suatu aplikasi permainan edukasi yang akan dijelaskan dengan menggunakan kerangka berpikir yang terdapat studi pendahuluan yang peneliti dapat berdasarkan survey dan wawancara, analisis kebutuhan data, analisis kebutuhan sistem, serta dengan metode sistem yang digunakan yaitu MDLC (Multimedia Development Life Cycle) dengan 6 tahapan yaitu

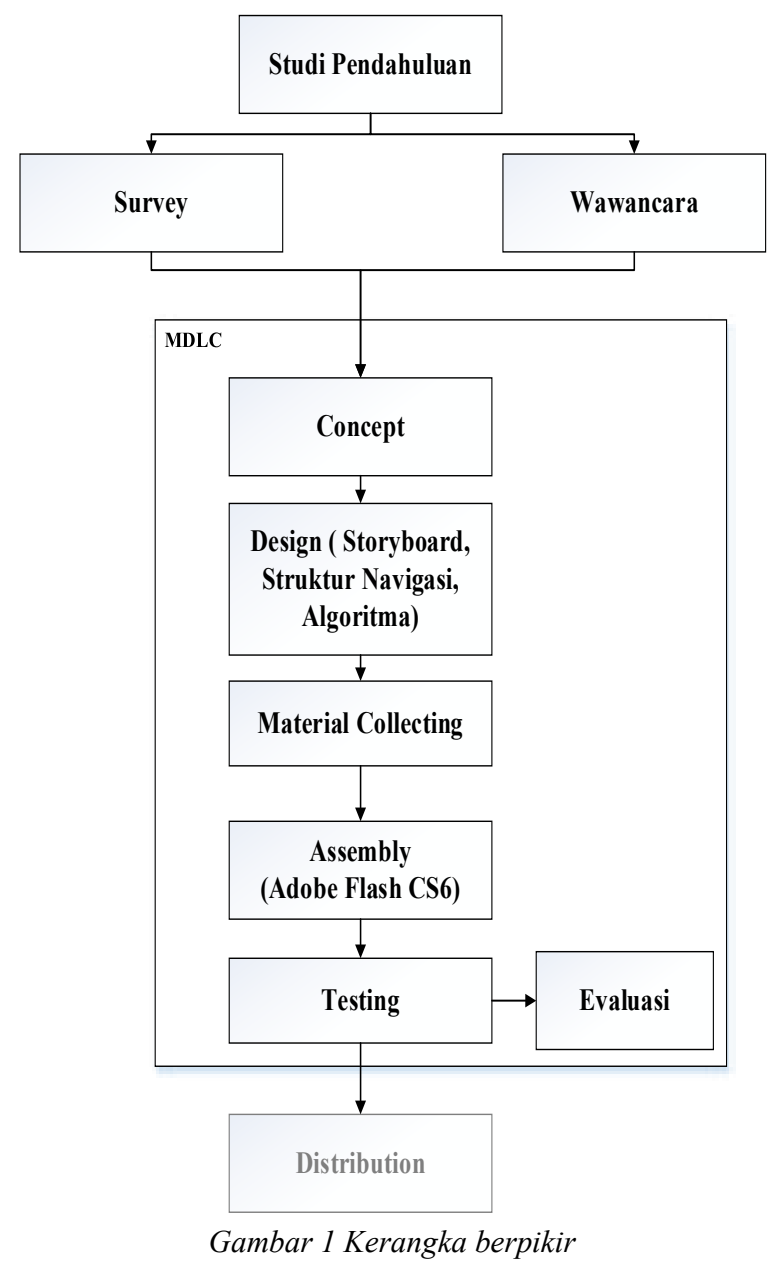


concept, design, material collecting, assembly, testing dan evaluasi.

Pada awal pengembangan sistem peneliti akan membuat suatu kerangka berpikir yang berguna untuk memberikan sebuah gambaran peneliti yang akan dilakukan. Tahapan-tahapan yang diperoleh melalui kerangka berpikir dapat membantu pengelola program untuk mengambil langkah-langkah penyesuaian yang diperlukan sedemikian rupa sehingga keuntungankeuntungan yang akan diterima oleh sasaran program dapat berjalan dengan baik. Kerangka berpikir yang di rancang oleh peneliti dapat di lihat pada Gambar 1 dari bagan yang ada pada gambar dapat dilihat bahwa peneliti akan melakukan beberapa seperti pada Gambar 1.

\section{Studi pendahuluan}

Peneliti melakukan pengamatan secara langsung dengan menggunakan survey ke sebuah sekolah dasar Strada Van Lith II dan melakukan wawancara untuk meminta izin kepada pihak sekolah dalam melakukan sebuah observasi di tempat tersebut.

\section{Tahapan-tahapan dari metode MDLC} (Multimedia Development Life Cycle)

\section{a. Concept}

Peneliti membuat konsep aplikasi multimedia mulai dari penelitian awal, judul aplikasi, tujuan penggunaan aplikasi, identifikasi pengguna, dan konsep aplikasi. Tahap ini adalah dimana peneliti terdapat tahapan lagi yaitu fungsional dan non fungsional, untuk mengetahui apa saja kebutuhan yang akan di bangun untuk membuat aplikasi multimedia permainan operasi hitung matematika seperti peneliti menanyakan kepada guru-guru kelas 1 dan kelas 2 materi apa saja yang diperlukan untuk dimasukkan kedalam permainan operasi hitung matematika dan dengan sistem pembelajaran yang ada pada sekolah dasar Strada Van Lith II yang masih menggunakan sistem manual, sehingga membutuhkan sebuah pengembangan sebuah sistem dalam media pembelajaran yang dapat membuat siswa-siswi kelas 1 dan kelas 2 lebih menyenangkan dalam mempelajari mata pelajaran matematika.

\section{b. Design}

Pada tahap design juga terdapat tahapan sebelum membuat sebuah aplikasi operasi hitung matematika menggunakan metode storyboard, struktur navigasi, dan algoritma: storyboard yaitu tool yang biasa di gunakan pada desain produksi film, animasi, Web site, dan video game. Selama pelaksanaan tahap desain, storyboard dapat memudahkan pengaturan scene, mengubah dan memodifikasi deskripsi, serta menambah atau menghilangkan bagian dari kelengkapan cerita yang telah dibuat untuk di perbaharui [4]; Struktur navigasi yaitu untuk pengembangan $w e b$, dan di adaptasi untuk pengembangan multimedia yang dibuat menggunakan bagan struktur dari awal permainan sampai akhir permainan operasi hitung matematika [4]; dan Algoritma yaitu untuk merancang sebuah aplikasi multimedia, berisi rangkaian instruksi yang saling terkait satu dengan lainnya (membentuk alur proses) dan tersusun secara terstruktur sedemikian hingga apabila program tersebut dijalankan akan dapat menghasilkan suat output seperti yang diharapkan [5].

\section{c. Material collecting}

Pada tahap material collecting yaitu berisi bahan apa saja yang di gunakan untuk membuat suatu aplikasi multimedia, serta berisi tentang background, backsound, teks, dan gambar apa saja yang diperlukan dalam membuat sebuah permainan edukasi operasi hitung matematika.

\section{d. Assembly}

Pada tahap ini peneliti ini berisi pembuatan animasi 2D, motion tween, animasi masking dan menjabarkan scriptyang digunakan untuk membangun sebuah aplikasi multimedia menggunakan Adobe Flash CS6 dengan Action Script 2.0.

\section{e. Testing}

Tahap ini adalah pengujian sistem yang telah dibangun oleh peneliti dan dapat di gunakan kepada para pengguna. Untuk tahap distribution yaitu tahap yang tidak di gunakan memerlukan cukup waktu yang lama sampai evaluasi selesai. Sehingga peneliti hanya membuat sampai testing saja, sehingga setelah testing maka memasuki tahapan evaluasi.

\section{f. Evaluasi}

Pada tahapan evaluasi yaitu berisi tentang screenshoot hasil tampilan permainan operasi hitung matematika dari awal sampai akhir permainan dan perhitungan kuesioner setelah melakukan presentasi aplikasi kekelas 1 dan kelas 2 SD Strada Van Lith II. Penelitian ini dilakukan sampai tahap testing dan evaluasi, untuk memenuhi kebutuhan permainan edukasi operasi hitung matematika. Sehingga pada tahap distribution tidak dilakukan dalam penelitian 
ini karna memerlukan penggunaan dengan waktu yang lama.

\section{HASIL DAN PEMBAHASAN}

Pembahasan berisikan mengenai kebutuhan sistem yang akan dibangun sebelum membuat suatu aplikasi permainan edukasi operasi hitung matematika yang menggunakan metode MDLC (Multimedia Development Life Cycle) yaitu pengembangan multimedia yang dilakukan dengan menggunakan 6 tahapan pada MDLC. Concept yaitu menentukan tujuan, termasuk identifikasi audiens, macam aplikasi, tujuan aplikasi, dan spesifikasi umum. Design yaitu membuat spesifikasi secara rinci mengenai arsitektur proyek, gaya dan kebutuhan material untuk proyek. Material Collecting yaitu pengumpulan bahan yang dapat dikerjakan parallel dengan tahap assembly. Assembly yaitu merupakan tahap dimana seluruh objek multimedia dibuat dan pembuatan aplikasi didasarkan dari tahapan design. Testing yaitu dilakukan setelah selesai tahap pembuatan dan seluruh data telah dimasukkan, pertama-tama dilakukan testing secara modular untuk memastikan apakah hasilnya seperti apa yang diinginkan [6].

\section{A. Concept}

Aplikasi permainan edukasi operasi hitung matematika adalah merupakan sebuah permainan yang mengandung materi pembelajaran untuk anak sekolah dasar dengan kebutuhan sistem yang mencangkup kebutuhan perangkat keras (hardware) yaitu dengan spesifikasi processor Intel Core i3, Harddisk 500GB, RAM 2GB, perangkat standar input serta output, sedangkan kebutuhan perangkat lunak (software) yaitu sistem operasi Windows, perangkat yang digunakan untuk editor/pembuatan aplikasi permainan edukasi operasi hitung matematika Adobe Flash CS6, Abode Photoshop.

Pada tahapan ini peneliti juga melakukan pengkonsepan, termasuk didalamnya melakukan penelitian awal yaitu berisi perhitungan kuesioner sebelum membuat suatu aplikasi permainan edukasi, tujuan pembuatan aplikasi yaitu membantu siswa dalam pelajaran matematika yang dapat digunakan sebagai media alternative untuk bermain sambil belajar pada siswa SD Strada Van Lith II, identifikasi pengguna yaitu hanya untuk kelas 1 dan kelas 2 SD Strada Van Lith II, dan konsep aplikasi yaitu mejelaskan tentang menu-menu apa saja yang ada pada permainan operasi hitung matematika serta dengan materi apa saja. Untuk materi permainan operasi hitung matematika hanya sampai dengan pengenalan angka, pertambahan, pengurangan, perkalian dan pembagian.

\section{B. Design}

Berdasarkan konsep permainan pada tahap sebelumnya, dilakukanlah perancangan pada permainan edukasi operasi hitung matematika berbasis multimedia. Pada tahap ini perancangan akan digambarkan dengan pembuatan storyboard, struktur navigasi, dan algoritma.

\section{Storyboard}

Pada perancangan storyboard, dapat memberikan gambaran visualisasi bagaimana proses scenario atau kegiatan aplikasi dari awal permainan sampai akhir permainan. Penggunaan storyboard ini nantinya akan menjelaskan berjalannya aplikasi yang dibuat pada Gambar 2.



Gambar 2 Storyboard

\section{Perancangan Struktur Navigasi}

Struktur navigasi yang digunakan adalah hierarchical model dengan sedikit modifikasi. Pada model ini dapat di lihat siswa setiap scene yang berhubungan dengan scene lainnya. Hasil yang dicapai dari perancangan struktur navigasi ini adalah memahami penulis dalam pembuatan rancangan bangun aplikasi operasi hitung pada mata pelajaran matematika kelas 1 dan 2 SD. Struktur navigasi yang ada pada aplikasi dapat dilihat pada Gambar 3.

\section{Alur Score Pada Menu Permainan Operasi Hitung Matematika}

Pada alur score menu permainan operasi hitung matematika ini akan di tunjukkan dengan menggunakan flowchart yaitu menggambarkan urutan 




Gambar 3 Struktur navigasi

logika dari suatu prosedur pemecahan masalah, yang dituliskan dalam simbol-simbol tertentu. Diagram alir ini akan menunjukkan alur didalam program secara logika, dan diagram alir ini sebagai alat komunikasi, juga diperlukan sebagai dokumentasi [5].

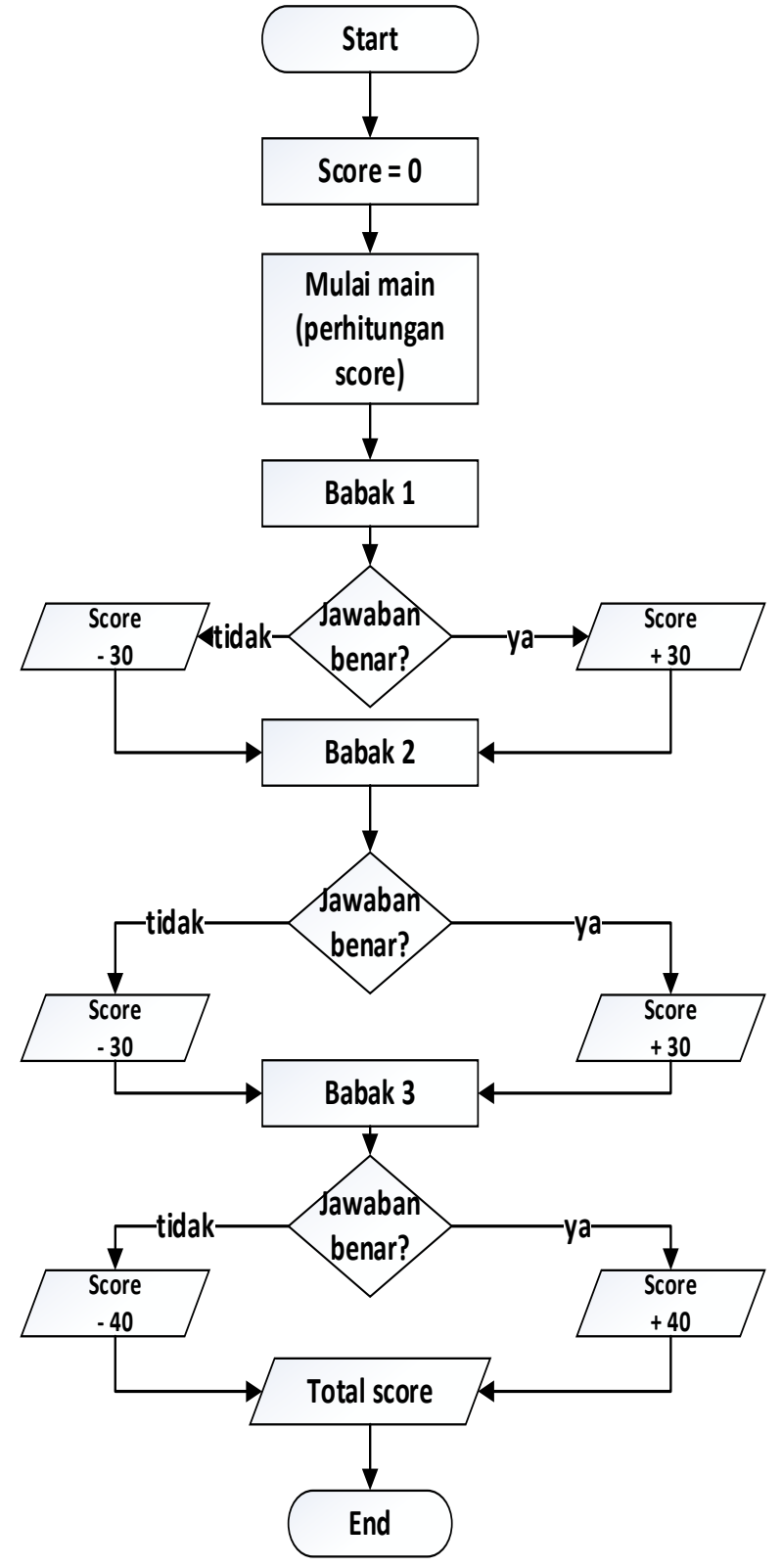

Gambar 4 Flowchart score menu permainan operasi hitung matematika
Pada Gambar 4 menjelaskan alur dari score pada menu permainan pertambahan, pengurangan, perkalian dan pembagian yang di mana setiap permainan memiliki perhitung dalam penentuan score. Perhitungan tersebut yang di bagi menjadi tiga babak yaitu babak pertama jika menjawab soal dengan benar maka akan di berikan score 30, babak ke dua jika menjawab soal dengan benar maka diberikan score 30 dan dibabak ketiga maka akan diberikan score 40. Score tersebut berdasarkan tingkat kesulitan soal dan apabila menjawab dengan salah maka score akan di kurangi sesuai dengan score yang ada dipenjelasan atas. Apabila mendapatkan score 100 maka akan muncul informasi "Selamat Anda Telah Menyelesaikannya..”, dan apabila mendapatkan score 60, 40, 20, -40, 100 maka akan muncul muncul informasi "Belajar Lebih Giat Lagi Ya..".

\section{Material Collecting}

Pada tahap material collecting ini, peneliti melakukan pengumpulan materi pembelajaran yang di dapat dari buku kelas 1 dan kelas 2 SD Strada Van Lith II dan peneliti juga mengambil materi tentang operasi hitung matematika kelas 1 dan kelas 2 SD dari sumber internet pengumpulan bahan yang dapat dikerjakan parallel dengan tahap assembly pengumpulan bahan yang dapat dikerjakan parallel dengan tahap assembly merupakan tahap dimana seluruh objek multimedia dibuat, dan pembuatan aplikasi didasarkan dari tahap design [6]. Bahan yang di kumpulkan untuk permainan

\begin{tabular}{|c|c|}
\hline Jub.l Taks & Jinis Font \\
\hline $\begin{array}{l}\text { Jubu halanan Gna, Menu Utana, } \\
\text { Penteagan Pemanan }\end{array}$ & Ara Rounded IMT boo \\
\hline Tontcl Mas,k (haltaman axa) & Aral Roundes MT Eoid \\
\hline 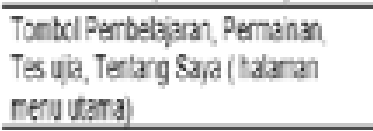 & Nial Fonted MT Boid \\
\hline Teks Serrry Darg & Ana Rounded MT cood \\
\hline  & Ara Founded MT soo \\
\hline Tontcl Mula (Menu Pembela aran) & Anal Rounces MT Eoid \\
\hline $\begin{array}{l}\text { Tontel Mulai (Permanan } \\
\text { Pengeraian Avgaj) }\end{array}$ & Gl Sans U tra Bab \\
\hline $\begin{array}{l}\text { Tortol Cara Veranian(Pernanan } \\
\text { Pengeraan Avog ] }\end{array}$ & Gisans Uto Bils \\
\hline $\begin{array}{l}\text { Tonbel Kelar (Cera Nenaingn } \\
\text { Pengerar Avgg) }\end{array}$ & Broxicuay \\
\hline $\begin{array}{l}\text { Tonbdi Augle 1.50 (Puntainen } \\
\text { Pungerajan Avgia) }\end{array}$ & Baxcar $5 \mathrm{x}$ \\
\hline  & Nial Rounted MT Boid \\
\hline
\end{tabular}




\begin{tabular}{|c|c|c|c|c|c|}
\hline $\begin{array}{l}\text { Doms } \\
\text { Conses }\end{array}$ & $\begin{array}{l}\text { Jenis U } \\
\text { Gambar }\end{array}$ & Ukinat & \multicolumn{3}{|c|}{ Simber } \\
\hline $\log$ Strata & b & 470 & \multirow{2}{*}{\multicolumn{3}{|c|}{  }} \\
\hline $\begin{array}{l}\text { Garter } \\
\text { atat }\end{array}$ & b & $1: 46$ & & & \\
\hline fonteolext & pq & 240 & \multicolumn{3}{|c|}{ tepinow coluctive contagext } \\
\hline $\begin{array}{l}\text { Exojound } \\
\text { mets iame } \\
\text { en } \\
\text { Pergerabn } \\
\text { Angia }\end{array}$ & b & 5456 & \multicolumn{3}{|c|}{ 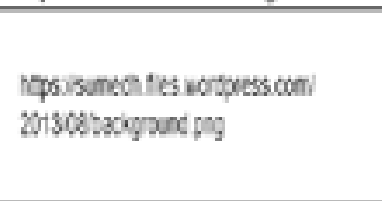 } \\
\hline sundon & is & $6 \mathrm{k}$ & \multicolumn{3}{|c|}{ 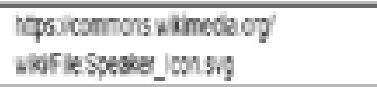 } \\
\hline Soundoe & pq & 170 & \multicolumn{3}{|c|}{ 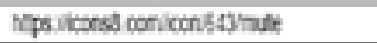 } \\
\hline $\begin{array}{l}\text { Garter } \\
\text { Anges 1,2, } \\
\text { A5 }\end{array}$ & pq & 46 & \multicolumn{3}{|c|}{ 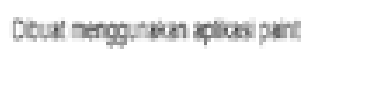 } \\
\hline $\begin{array}{l}\text { Gartar } \\
\text { Aoga } 3\end{array}$ & $b$ & 56 & \multicolumn{3}{|c|}{ Deuat nenguraten walies part } \\
\hline $\begin{array}{l}\text { Gartar } \\
\text { Burag Oal }\end{array}$ & $b$ & 21216 & \multicolumn{3}{|c|}{ 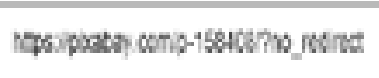 } \\
\hline $\operatorname{Foph} 7 / \mathrm{s}$ & bg & 1986 & \multicolumn{3}{|c|}{ 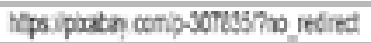 } \\
\hline \multirow[t]{32}{*}{$\begin{array}{l}\text { Batse } 2 \\
\text { sanpa } 6\end{array}$} & ipg & 500 & \multicolumn{3}{|c|}{ Dbux nenggrakan zollos pant } \\
\hline & & Gamb & bar 6 & Bahan ge & \\
\hline & Nama Suara & $\begin{array}{ll}\mathrm{de} \\
\mathrm{d}\end{array}$ & $\begin{array}{l}\text { enis } \\
\text { ivara }\end{array}$ & Uhuran & Sunber \\
\hline & Argea 1 & & nI & 96,46 & Relem \\
\hline & Angaza & & IIOV & 1306 & Reran \\
\hline & Anga 3 & & GV & $40.5 \mathrm{ib}$ & Reran \\
\hline & Anok 4 & & av & 3800 & Rean \\
\hline & Andat 5 & & av & 37,26 & Rean \\
\hline & Angkad & & wov & 28,046 & Rodon \\
\hline & Angla 7 & & $\pi$ & 98,46 & Relen \\
\hline & Angas & & IaV & 48,56 & Recan \\
\hline & Anoka ? & & IaV & 48.26 & Rean \\
\hline & Anoca 10 & & ave & $450 \mathrm{ch}$ & Reian \\
\hline & Ancia 11 & & av & $51,8 \mathrm{~b}$ & Rean \\
\hline & Angka f? & & $\overline{a g}$ & 50,56 & Rean \\
\hline & Argla 13 & & $\overline{n g}$ & 38.56 & Relan \\
\hline & Anga 14 & & IaV & 5,76 & Rean \\
\hline & Anoca is & & iar & 23006 & Recan \\
\hline & Anqua 18 & & ad & $385 \mathrm{ch}$ & Reian \\
\hline & Anoka 17 & & wov & 80,86 & Rean \\
\hline & Anoka ID & & $\mathrm{agr}$ & $70,8 \mathrm{~d}$ & Rean \\
\hline & Arga it & & IISVI & 78,86 & Recan \\
\hline & Anga2 & & IIG & 4.26 & Rean \\
\hline & Aroga 21 & & IaV & 00.86 & Recan \\
\hline & Anca $\%$ & & ast & $50.7 \mathrm{ch}$ & Reiam \\
\hline & Anoka 28 & & wov & $51,0 \mathrm{~b}$ & Relon \\
\hline & Angka 24 & & agr & 55.26 & Rean \\
\hline & Anga 25 & & IIIS & 47,36 & Recan \\
\hline & Anoga & & IFV & $\$ 3.36$ & Rean \\
\hline & Anoga 27 & & If & 5.26 & Recan \\
\hline & $\begin{array}{l}\text { Angua } 28 \\
\text { Sampai } 50\end{array}$ & & nav & 87,56 & Rean \\
\hline & Othe war & & Eg & $90.2 \pi 6$ & Hegs dowis \\
\hline
\end{tabular}

operasi hitung matematika adalah gambar, tampilan pendukung background apa saja yang digunakan dalam permainan operasi hitung matematika, teks font apa saja yang sesuai untuk permainan edukasi operasi hitung matematika pada kelas 1 dan kelas 2 sekolah dasar, animasi, dan backsound apa saja yang sesuai dengan murid kelas 1 dan kelas 2. Sebagian gambar dan teks dibuat sendiri pada perangkat lunak Adobe Flash CS6, Adobe Photoshop dan Paint, serta foto yang dibuat sendiri menggunakan kamera yang terdapat pada Gambar 5, Gambar 6, dan Gambar 7.

\section{Assembly}

Pada tahap ini semua objek atau bahan multimedia di buat. Pembuatan permainan operasi hitung matematika di dasarkan pada tahap pembuatan game yang disertai dengan ActionScript. Perangkat lunak authoring yaitu perangkat lunak yang dapat di pergunakan untuk membuat dan penyampaian konten multimedia seperti teks, gambar, grafik, suara, animasi dan video kepada pengguna. Pada tahap ini menggunakan Adobe Flash CS6. Pengkodean program menggunakan Action Script 2.0. Bahan yang telah dikumpulkan untuk membuat permainan operasi hitung matematika selanjutnya di import ke dalam library Adobe Flash CS6.

Berikut ini merupakan hasil dan evaluasi perancangan permainan edukasi operasi hitung matematika pada SD Strada Van Lith II yang akan dibangun oleh peneliti. Sistem ini terdiri dari halaman input nama, pengguna akan memasukan nama terlebih dahulu. Apabila pengguna tidak memasukkan nama, maka akan muncul informasi "Silakan Isi Nama Anda" dan terdapat tombol exit/keluar aplikasi. Setelah memasukkan nama pengguna, lalu akan masuk ke halaman selanjutnya. Tampilan halaman input nama pada permainan edukasi operasi hitung matematika di tunjukkan pada Gambar 8 .

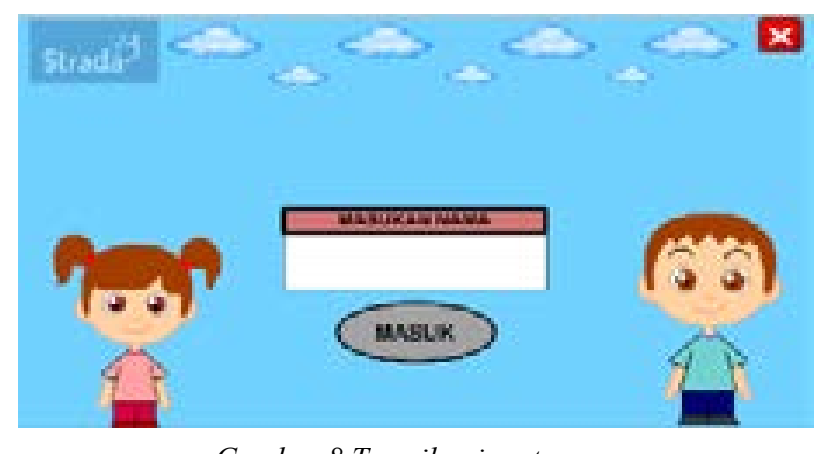

Gambar 8 Tampilan input nama

\section{Tampilan Menu Utama}

Pada halaman menu utama, setelah input nama maka pengguna akan masuk ke halaman menu utama. Nama yang sudah dimasukkan akan muncul pada animasi yang ada di menu utama dan di menu utama terdapat beberapa menu yaitu pembelajaran, permainan, tes ujian, tentang saya, dan tombol turn on/off suara, tombol exit/keluar. apabila pengguna mengklik salah satu menu yang ada maka akan 
langsung ke halaman selanjutnya. Tampilan halaman menu utama pada permainan edukasi operasi hitung matematika ditunjukkan pada Gambar 9.

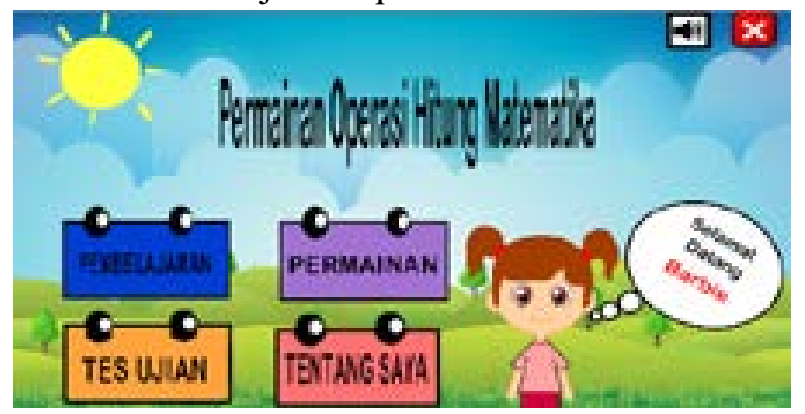

Gambar 9 Tampilan menu utama

\section{Tampilan Menu Pembelajaran}

Pada tampilan menu pembelajaran, pengguna dapat memilih/mengklik menu lagi yang diinginkan dalam menu pembelajaran yaitu pembelajaran pengenalan angka, pertambahan, pengurangan, perkalian, pembagian, dan tombol turn on/off suara, exit/keluar kemenu utama. Dimana setiap menu pembelajaran terdapat materi sesuai dengan yang dipilih oleh pengguna. Tampilan halaman menu pembelajaran pada permainan edukasi operasi hitung matematika ditunjukkan pada Gambar 10.

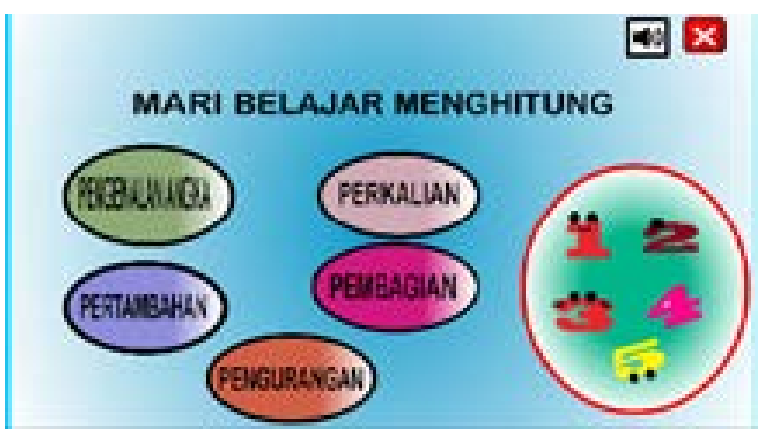

Gambar 10 Tampilan menu pembelajaran

Pada Gambar 11 materipembelajaran pengenalan angka yang terdapat tombol mulai dan tombol exit/ keluar untuk kembali kemenu pembelajaran. Dan ketika tombol mulai diklik, maka pengguna memasuki halaman materi pengenalan angka 1 sampai angka 50 disertakan penjabaran tulisan angka yang ada pada materi pembelajaran pengenalan angka, sehingga pengguna dapat lebih focus dan memahami materi yang ada pada pembelajaran pengenalan angka.

Pada Gambar 12 materi pembelajaran pertambahan yang terdapat tombol mulai dan tombol exit/keluar untuk kembali kemenu pembelajaran. Dan ketika tombol mulai diklik, maka pengguna memasuki halaman materi perhitungan pertambahan mulai dari angka 1 sampai angka 10, sehingga pengguna dapat lebih focus dan memahami materi yang ada pada pembelajaran pertambahan.


Pada Gambar 13 materi pembelajaran pengurangan yang terdapat tombol mulai dan tombol exit/keluar untuk kembali kemenu pembelajaran. Dan ketika tombol mulai diklik, maka pengguna memasuki halaman materi perhitungan pengurangan mulai dari angka 1 sampai angka 10, sehingga pengguna dapat lebih focus dan memahami materi yang ada pada pembelajaran pengurangan.

Pada Gambar 14 materi pembelajaran perkalian yang terdapat tombol mulai dan tombol exit/keluar untuk kembali kemenu pembelajaran. Dan ketika tombol mulai diklik, maka pengguna memasuki 


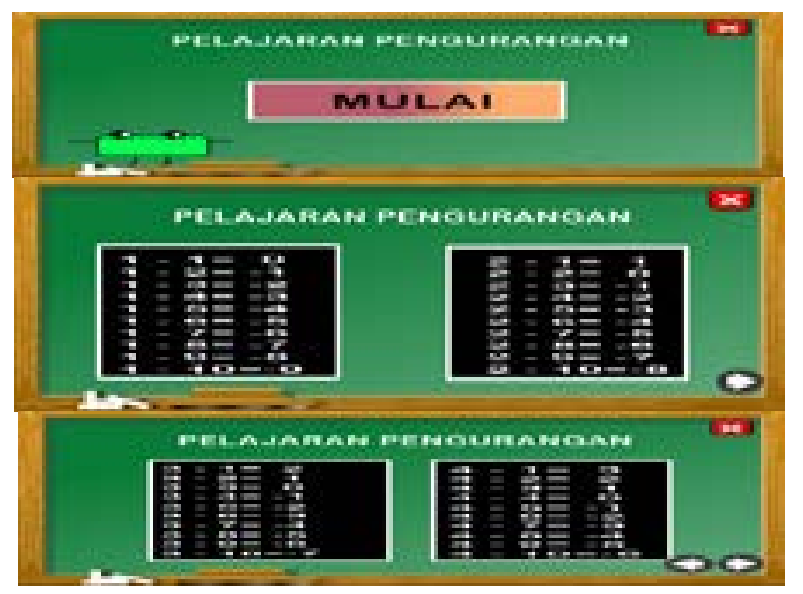

Gambar 13 Isi materi perhitungan pengurangan 1 sampai 10

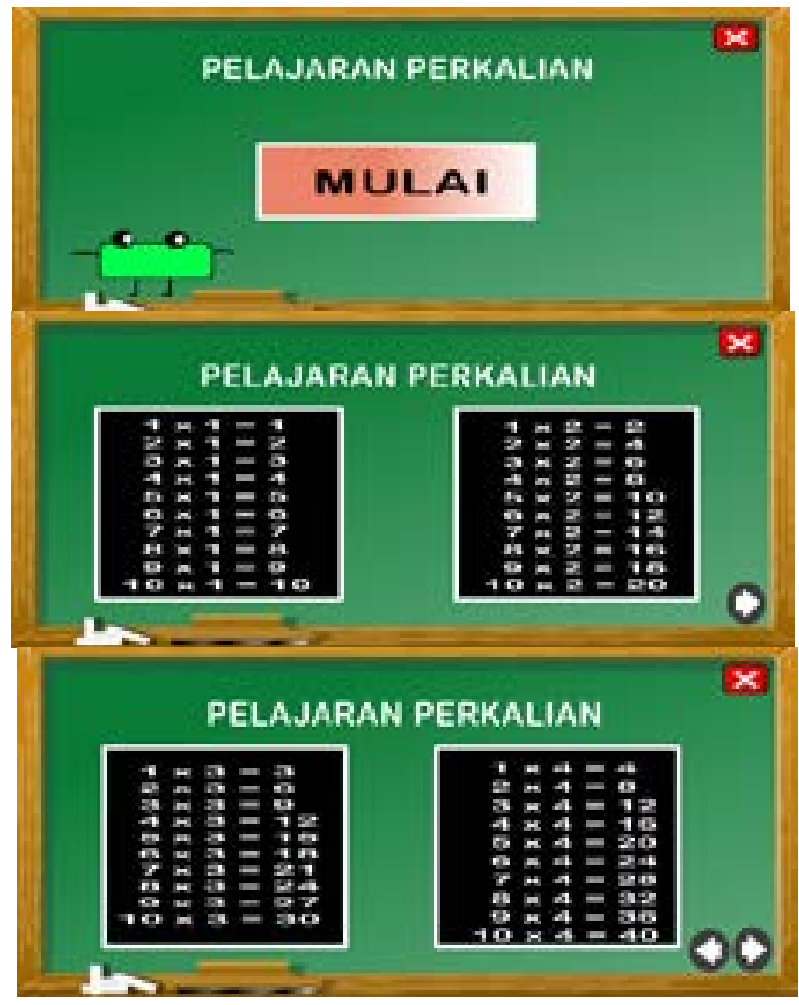

Gambar 14 Isi materi perhitungan perkalian 1 sampai 10

halaman materi perhitungan perkalian mulai dari angka 1 sampai angka 10, sehingga pengguna dapat lebih focus dan memahami materi yang ada pada pembelajaran perkalian.

Pada Gambar 15 memasuki materi pembelajaran pembagian yang terdapat tombol mulai dan tombol exit/keluar untuk kembali kemenu pembelajaran. Dan ketika tombol mulai diklik, maka pengguna memasuki halaman materi perhitungan pembagian mulai dari angka 1 sampai angka 10, sehingga pengguna dapat lebih focus dan memahami materi yang ada pada pembelajaran pembagian.

\section{Tampilan Menu Permainan}

Pada tampilan menu permainan, pengguna dapat memilih/mengklik menu lagi yang di inginkan dalam

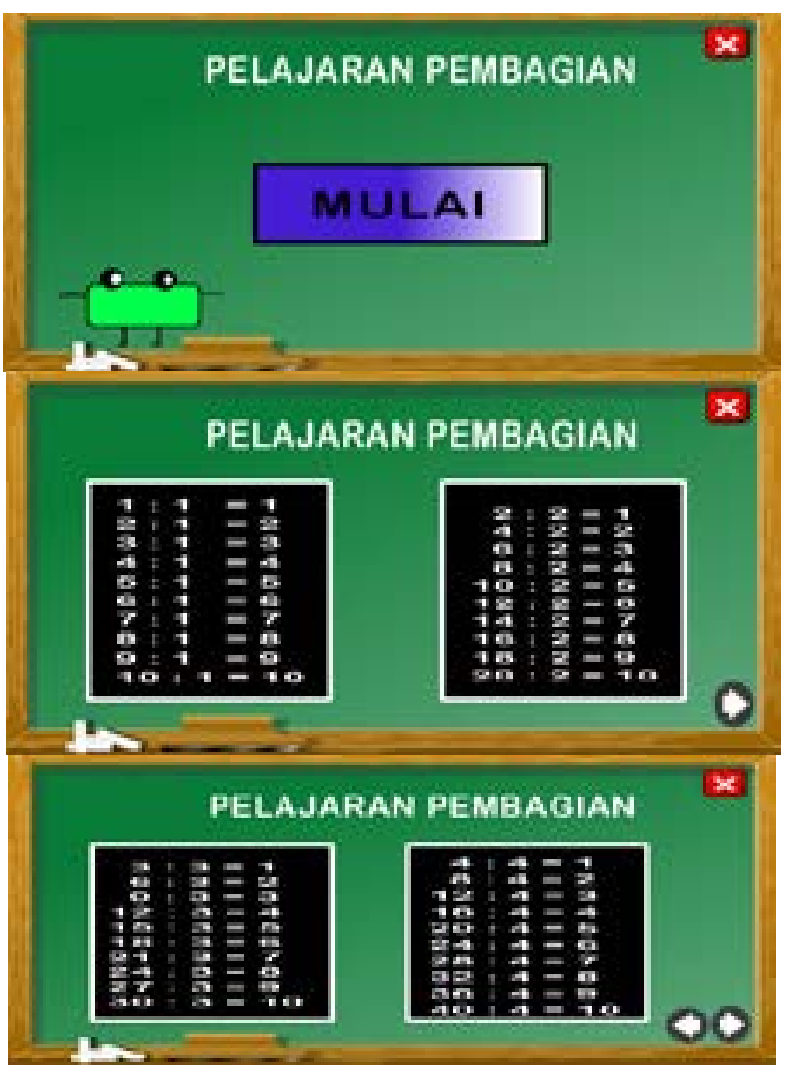

Gambar 15 Isi materi perhitugan pembagian 1 sampai 10

menu permainan sesuai dengan level yang ada pada menu permainan yaitu level mudah terdapat menu permainan pengenalan angka, level sedang terdapat menu permainan pertambahan dan pengurangan, level sulit yaitu terdapat menu permainan perkalian dan pembagian. Serta terdapat tombol turn on/off untuk suara, tombol exit/keluar kemenu utama.

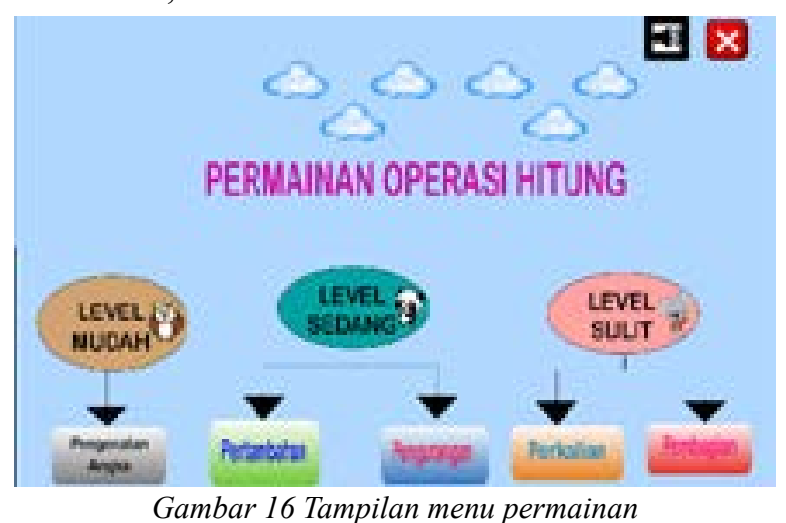

\section{Tampilan Permainan Pengenalan Angka}

Pada Gambar 17 tampilan permainan pengenalan angka terdapat 2 tombol yaitu ada tombol mulai dan tombol cara memainkan, tombol exit/keluar kemenu permainan. apabila pengguna terlebih dahulu melihat/ mengklik tombol cara memainkan pengenalan angka, maka pengguna dapat memahami cara permainan penganalan angka sebelum memulainya setelah melihat cara memainkkannya lalu pengguna bisa 
langsung mulai permainannya dengan cara mengklik/ memilih tombol angka yang apabila klik maka akan keluar suara angka yang pengguna pilih.

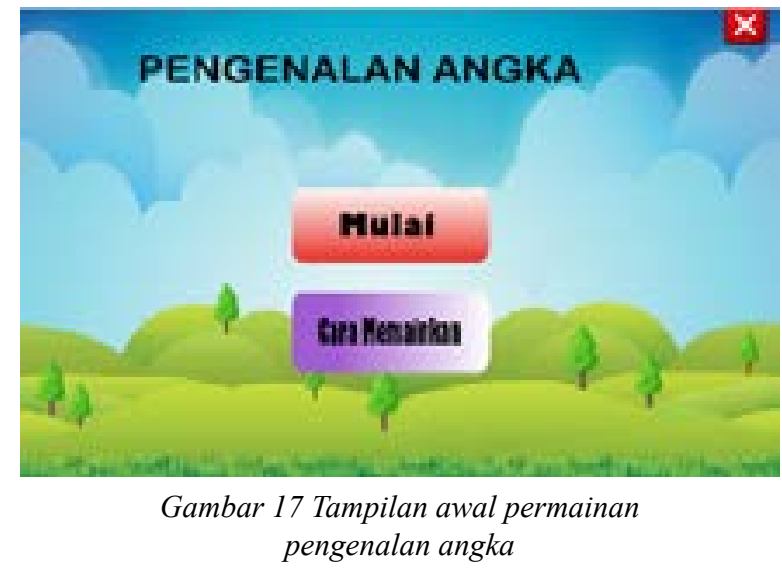

Pada Gambar 18 menjelaskan cara memainkan permainan pengenalan angka yang disertai dengan adanya gambar awal permainan pada kotak yang ada. Apabila sudah memahami cara memainkannya, maka langsung klik tombol keluar untuk kembali kehalaman awal permainan pengenalan angka.

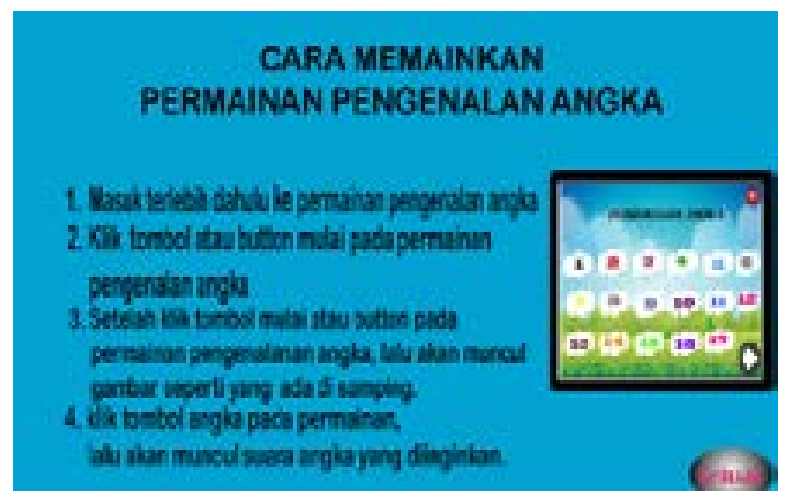

Gambar 18 Rancangan halaman cek data supplier

Pada Gambar 19 menjelaskan permainan pengenalan angka dari angka 1 sampai angka 50 . Apabila diklik tombol awan yang terdapat teks angka, maka akan muncul suara sesuai dengan angka yang diklik. Lalu setelah mendengarkan semua suara angka yang di inginkan, lalu klik tombol panah yang ada disamping bawah untuk melihat permainan pengenalan angka selanjutnya dan apabila tidak ingin melanjutkan permainan pengenalan angka maka dapat langsung diklik tombol X untuk kembali kemenu permainan.

\section{Tampilan Permainan Pertambahan}

Pada tampilan permainan pertambahan terdapat 2 tombol yaitu ada tombol mulai dan tombol cara memainkan, tombol exit/keluar kemenu permainan. apabila pengguna terlebih dahulu melihat/mengklik tombol cara memainkan pertambahan, maka pengguna dapat memahami cara permainan pertambahan

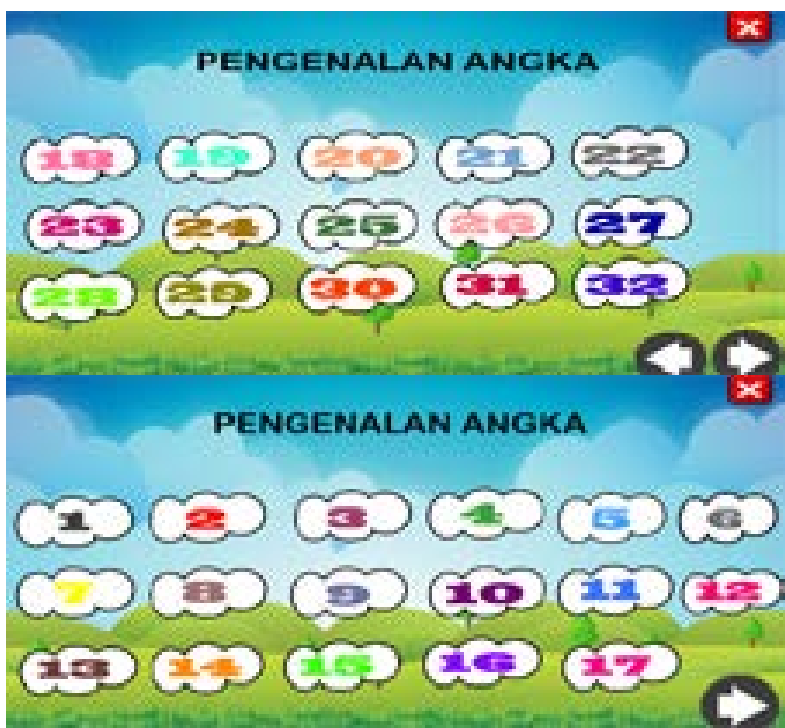

Gambar 19 Tampilan permainan

pengenalan angka 1 sampai 50

terlebih dahulu karna di permainan terdapat 3 soal yang berbeda-beda dan dengan cara menjawab yang berbeda-beda.

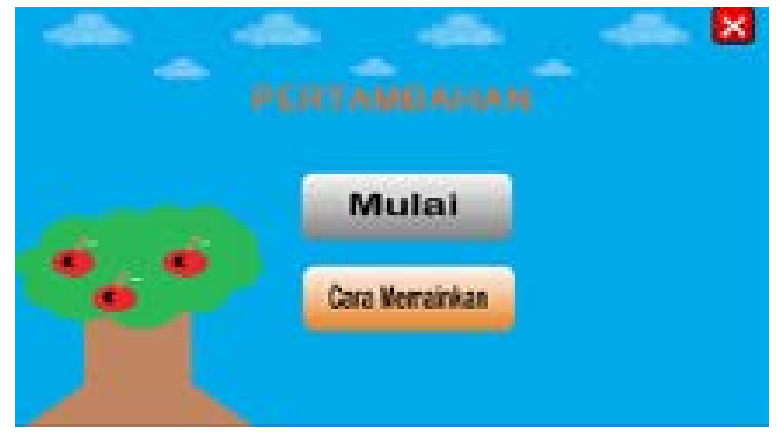

Gambar 20 Rancanngan menu admin

Pada Gambar 21 adalah cara memainkan permainan pertambahan yang mempunyai 3 permainan yang berbeda-beda seperti permainan pertama yaitu memasukkan angka pada kotak kosong, dan angkanya tersebut terdapat pada gambar benda, kupu-kupu, panda. Permainan kedua yaitu permainan drag and drop yang dimana suatu objek di drag, lalu objek tersebut di drop ke target yang ada pada gambar. Permainan ketiga yaitu permainan yang berkonten pilihan ganda dan disertai dengan adanya gambar permainan pada kotak yang ada. Apabila sudah

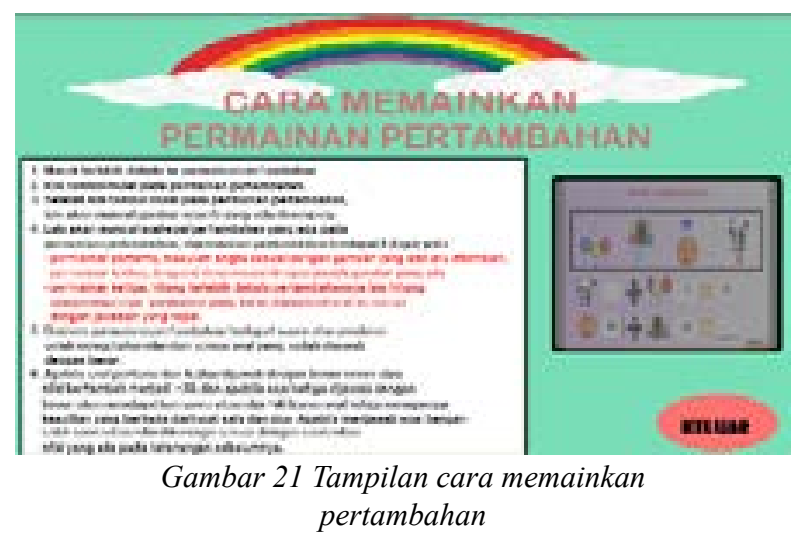


memahami cara memainkannya, maka langsung klik tombol keluar untuk kembali kehalaman awal permainan pertambahan.

Pada Gambar 22 adalah permainan pertambahan pertama yang mempunyai 2 pertanyaan. Pertanyaan pertama yaitu memasukkan angka sesuai dengan gambar yang ada pada jumlah gambar balon, kupukupu, bola basket, dan panda. Pertanyaan kedua yaitu menghitung gambar bola yang sudah ada angkanya lalu ditambah dengan angka gambar kupu-kupu pada bilangan bulat dari pertanyaan pertambahan yang ada. Apabila sudah selesai menjawab semua soal yang ada, lalu klik tombol next untuk kepermainan yang selanjutnya.



Gambar 22 Tampilan permainan pertambahan soal pertama

Pada Gambar 23 adalah permainan pertambahan kedua yaitu permainan drag and drop yang dimana suatu objek di drag lalu drop sesuai dengan jumlah gambar panda, awan dan pelangi. Apabila sudah selesai menjawab semua soal yang ada, maka akan langsung next ke permainan selanjutnya.

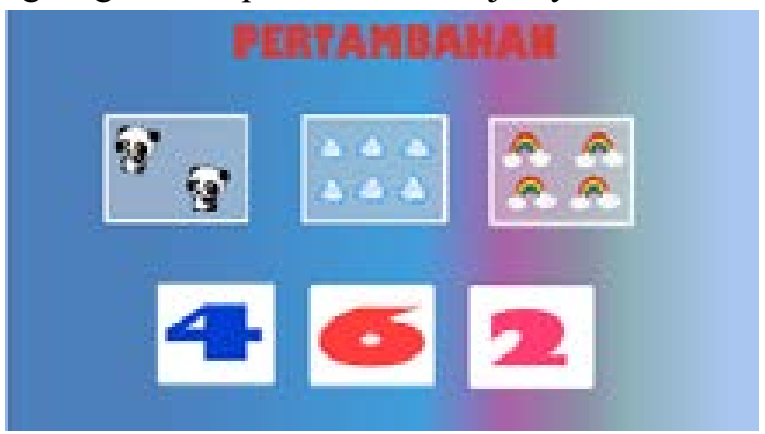

Gambar 23 Tampilan permainan pertambahan soal kedua

Pada Gambar 24 adalah permainan pertambahan ketiga yaitu permainan yang berbentuk soal pilihan ganda, yang dapat dihitung lebih dahulu pertambahannya, lalu setelah mendapatkan hasil dari pertambahan lalu dikurang dengan angka yang ada pada soal. Apabila sudah selesai menjawab semua soal yang ada, maka akan next kehalaman selanjutnya yaitu total score.

Pada Gambar 25 adalah tampilan total score setelah menyelesaikan permainan pertambahan pertama sampai ketiga. Apabila soal terjawab

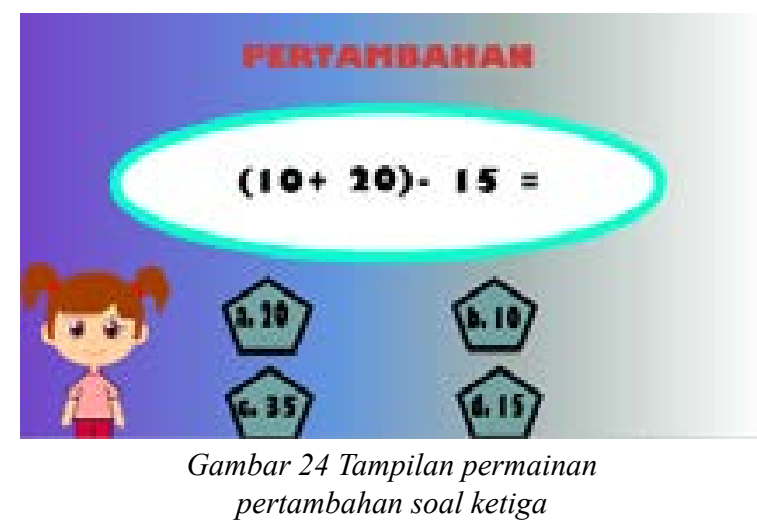

dengan benar semua maka akan mendapatkan score 100 dengan informasi "Selamat Anda Telah Menyelesaikannya..", sedangkan apabila pengguna menjawab soal dengan salah maka akan mendapatkan score 60, 40, 20, -40, -100 dengan informasi "Belajar Lebih Giat Lagi Ya..!”. Setelah selesai melihat score nya, lalu klik tombol kembali ke menu permainan, untuk kembali ke menu permainan.

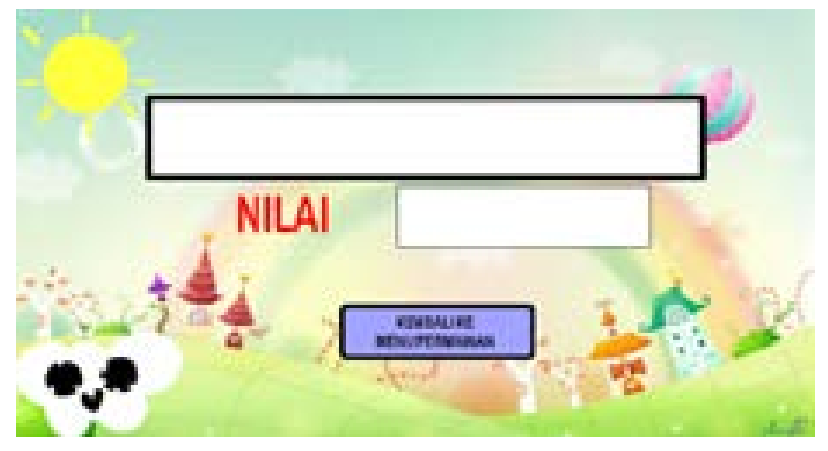

Gambar 25 Tampilan hasil akhir permainan pertambahan

\section{Tampilan Permainan Pengurangan}

Pada tampilan permainan pengurangan terdapat 2 tombol yaitu ada tombol mulai dan tombol cara memainkan, tombol exit/keluar kemenu permainan. apabila pengguna terlebih dahulu melihat/mengklik tombol cara memainkan pengurangan, maka pengguna dapat memahami cara permainan pengurangan terlebih dahulu karna di permainan terdapat 3 soal yang berbeda-beda dan dengan cara menjawab yang berbeda-beda.

Pada Gambar 27 adalah cara memainkan permainan pengurangan yang mempunyai 3 permainan yang berbeda-beda seperti permainan pertama yaitu permainan pengurangan yang menggunakan pilihan ganda untuk menjawab pertanyaan yang ada. Permainan kedua yaitu permainan memasukkan jumlah burung pada kotak satu lalu dikurang dengan jumlah burung kotak dua setelah selesai menghitungnya, lalu masukkan jumlahnya pada kotak jawaban atau kosong. Permainan ketiga yaitu permainan yang berkonten 


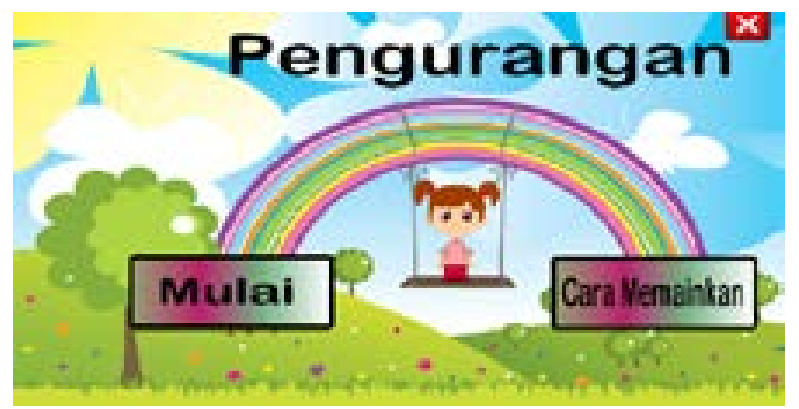

Gambar 26 Tampilan permainan pengurangan

pilihan ganda. Dan pada cara permainan terdapat soal pengurangan dan pertambahan yang harus dihitung terlebih dahulu untuk menjawab soal yang ada. Apabila sudah memahami cara memainkannya, maka langsung klik tombol keluar untuk kembali kehalaman awal permainan pengurangan.

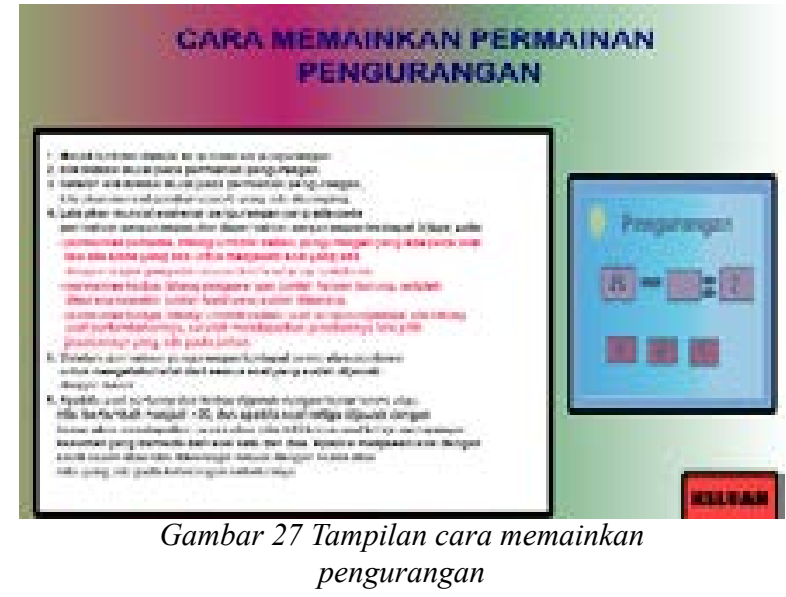

Pada Gambar 28 adalah permainan pengurangan pertama yaitu permainan yang berbentuk soal pilihan ganda, yang dapat dihitung terlebih dahulu soal pengurangan yang mendapatkan hasil angka 2, lalu apabila menjawab soal dengan benar atau salah, maka akan langsung next ke permainan selanjutnya.

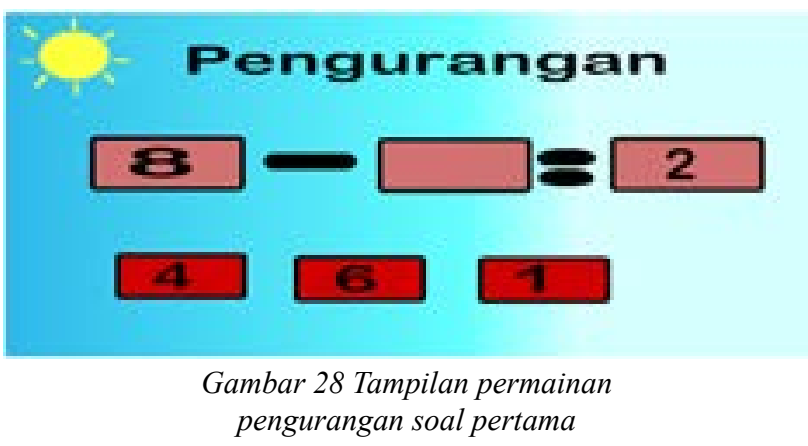

Pada Gambar 29 adalah permainan pengurangan kedua yaitu permainan dengan cara menghitung jumlah hewan burung terlebih dahulu, lalu di hitung pengurangannya, setelah mendapatkan jawabannya, langsung masukkan ke dalam kotak jawabannya. Apabila sudah selesai menjawab semua soal yang ada, lalu klik tombol next untuk kepermainan selanjutnya.



Pada Gambar 30 adalah permainan pengurangan ketiga yaitu permainan yang berbentuk soal pilihan ganda, yang dapat dihitung terlebih dahulu soal pengurangannya setelah mendapatkan hasilnya, lalu tambah dengan soal yang ada. Dan pilih jawaban pada pohon buah apel yang terdapat tombol angka untuk memilih jawabannya, apabila menjawab soal dengan benar atau salah, maka akan langsung next ke tampilan score atau perhitungan score semuanya.



Pada Gambar 31 adalah tampilan total score setelah menyelesaikan permainan pengurangan pertama sampai permainan pengurangan ketiga. Apabila soal terjawab dengan benar semua maka mendapatkan score 100 dengan informasi "Selamat Anda Telah Menyelesaikannya..”, sedangkan apabila pengguna menjawab soal dengan salah maka mendapatkan score 60, 40, 20, -40,-100 dengan informasi "Belajar Lebih Giat Lagi Ya..!". Setelah selesai melihat score nya, lalu klik tombol kembali ke menu permainan, untuk kembali ke menu permainan.

\section{Tampilan Permainan Perkalian}

Pada tampilan permainan perkalian terdapat 2 tombol yaitu ada tombol mulai dan tombol cara memainkan, tombol exit/keluar kemenu permainan. apabila pengguna terlebih dahulu melihat/mengklik tombol cara memainkan perkalian, maka pengguna dapat memahami cara permainan perkalian terlebih dahulu karna dipermainan terdapat 3 soal yang berbeda-beda dan dengan cara menjawab yang berbeda-beda. 


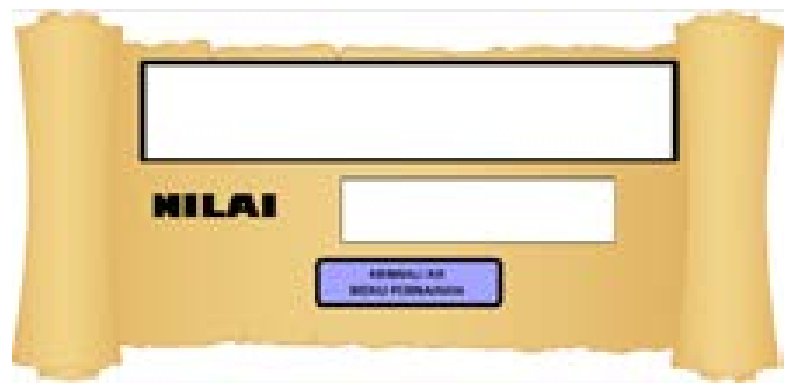

Gambar 31 Tampilan hasil akhir permainan pengurangan



Gambar 32 Tampilan awal permainan perkalian

Pada Gambar 33 adalah cara memainkan permainan perkalian yang mempunyai 3 permainan yang berbeda-beda seperti permainan pertama yaitu permainan drag and drop. Permainan kedua yaitu permainan dengan cara menghitung jumlah gambar kupu-kupu, gelas minuman, mobil yang ada pada kotak terlebih dahulu, lalu masukkan jumlah yang sudah di hitung ke kotak jumlah angka 1, jumlah angka 2 dan jawaban dan klik tombol next untuk kesoal selanjutnya. Permainan ketiga yaitu permainan yang berkonten pilihan ganda. Apabila sudah memahami cara memainkannya, maka langsung klik tombol keluar untuk kembali kehalaman awal yaitu permainan perkalian.

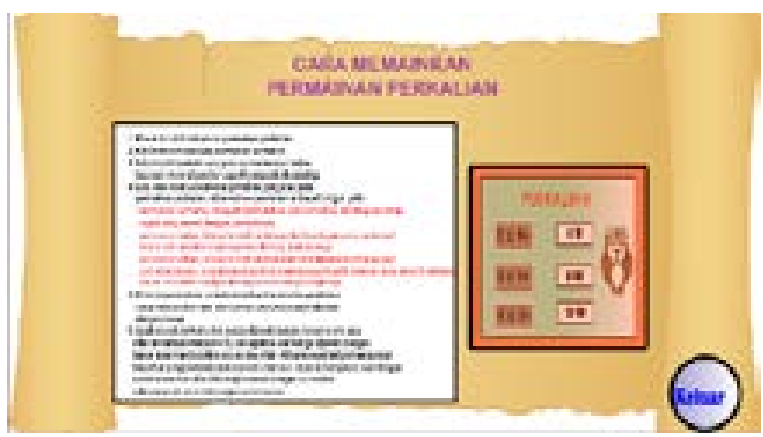

Gambar 33 Tampilan cara memainkan perkalian

Pada Gambar 34 adalah permainan perkalian pertama yaitu permainan drag and drop yang dimana suatu objek di drag lalu drop sesuai dengan soal perkalian yang ada. Apabila sudah selesai menjawab semua soal yang ada, maka akan langsung next ke permainan selanjutnya.

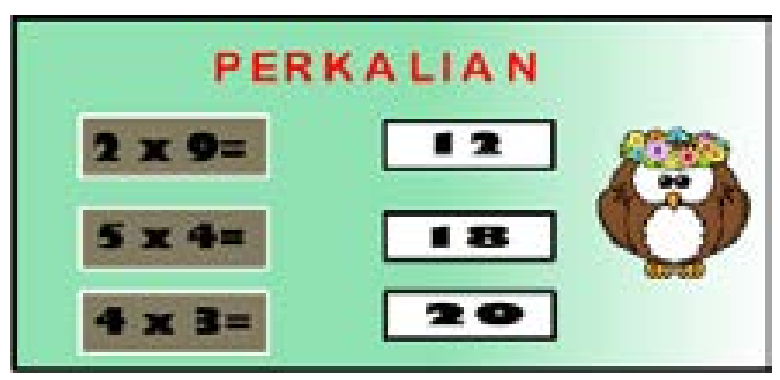

Gambar 34 Tampilan permainan perkalian soal pertama

Pada Gambar 35 adalah permainan perkalian kedua yaitu permainan dengan cara menghitung jumlah gambar kupu-kupu, gelas minuman, mobil yang ada pada kotak terlebih dahulu, lalu masukkan jumlah yang sudah di hitung ke kotak jumlah angka 1 , jumlah angka 2 dan jawaban dan klik tombol next untuk kepermainan selanjutnya.



Gambar 35 Tampilan permainan perkalian soal kedua

Pada Gambar 36 adalah permainan perkalian ketiga yaitu permainan yang berkonten pilihan ganda dan disertai dengan adanya soal perkalian dan pertambahan yang harus dihitung terlebih dahulu untuk menjawab soal yang ada pada buah jeruk. Apabila sudah selesai menjawabnya, maka klik tombol next untuk ke halaman score.



Pada Gambar 37 adalah tampilan total score setelah menyelesaikan permainan perkalian pertama sampai permainan perkalian ketiga. Apabila soal terjawab dengan benar semua maka mendapatkan 
score 100 dengan informasi "Selamat Anda Telah Menyelesaikannya..", sedangkan apabila pengguna menjawab soal dengan salah maka mendapatkan score 60, 40, 20, -40, -100 dengan informasi "Belajar Lebih Giat Lagi Ya..!". Setelah selesai melihat score nya, lalu klik tombol kembali ke menu permainan, untuk kembali ke menu permainan.

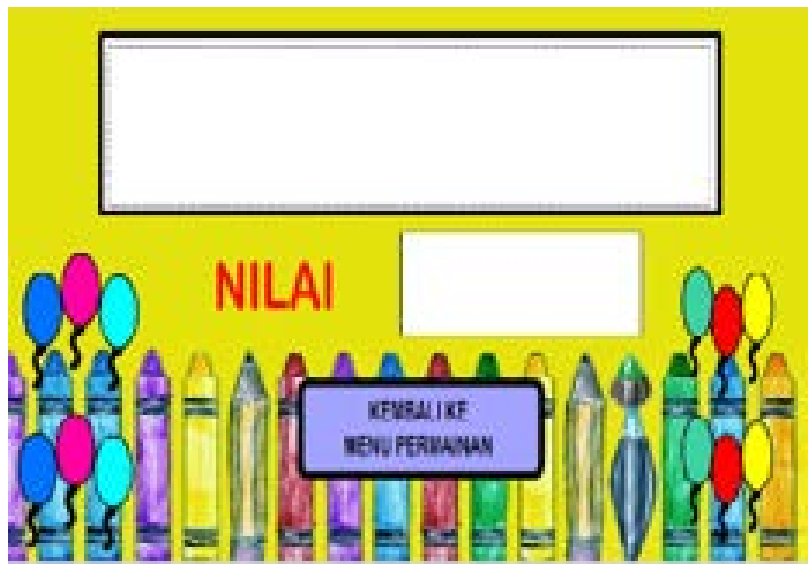

Gambar 37 Tampilan hasil akhir permainan perkalian

\section{Tampilan Permainan Pembagian}

Pada tampilan permainan perkalian terdapat 2 tombol yaitu ada tombol mulai dan tombol cara memainkan, tombol exit/keluar kemenu permainan. apabila pengguna terlebih dahulu melihat/mengklik tombol cara memainkan pembagian, maka pengguna dapat memahami cara permainan pembagian terlebih dahulu karna di permainan terdapat 3 soal yang berbeda-beda dan dengan cara menjawab yang berbeda-beda. Setelah pengguna melihat cara memainkannya, maka pengguna bisa langsung memulai permainan.

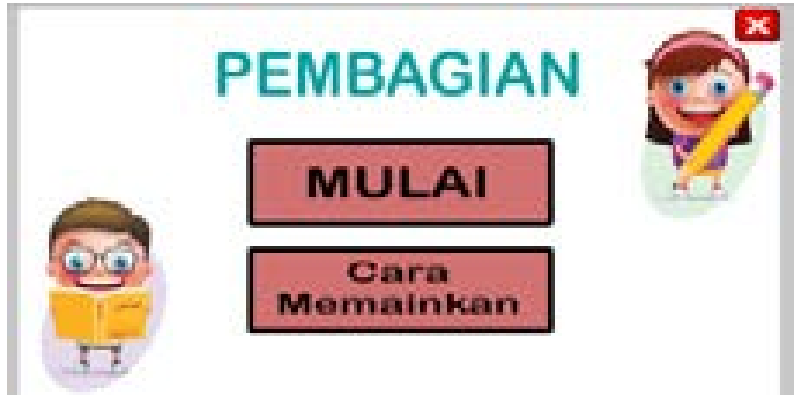

Gambar 38 Tampilan awal permainan pembagian

Pada Gambar 39 adalah cara memainkan permainan pembagian yang mempunyai 3 permainan yang berbeda-beda seperti permainan pertama yaitu permainan yang berbentuk soal essay, setelah selesai mengisi jawabannya lalu klik tombol next untuk ke permainan selanjutnya. Permainan kedua yaitu permainan yang berbentuk soal essay yang dapat menggunakan kalkulator untuk menghitungnya, lalu klik tombol next untuk ke permainan selanjutnya. Permainan ketiga yaitu permainan yang berkonten pilihan ganda. Apabila sudah memahami cara memainkannya, maka langsung klik tombol keluar untuk kembali kehalaman awal permainan perkalian.

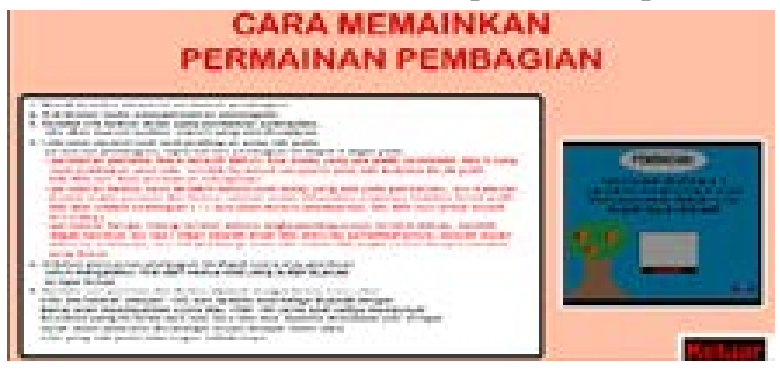

Gambar 39 Tampilan cara memainkan pembagian

Pada Gambar 40 adalah permainan pembagian pertama yaitu permainan yang berbentuk soal essay, setelah selesai menghitung pembagiannya lalu masukkan jumlahnya kekotak jawaban. Apabila sudah selesai menjawab semua soal yang ada, maka klik tombol next untuk ke permainan selanjutnya.

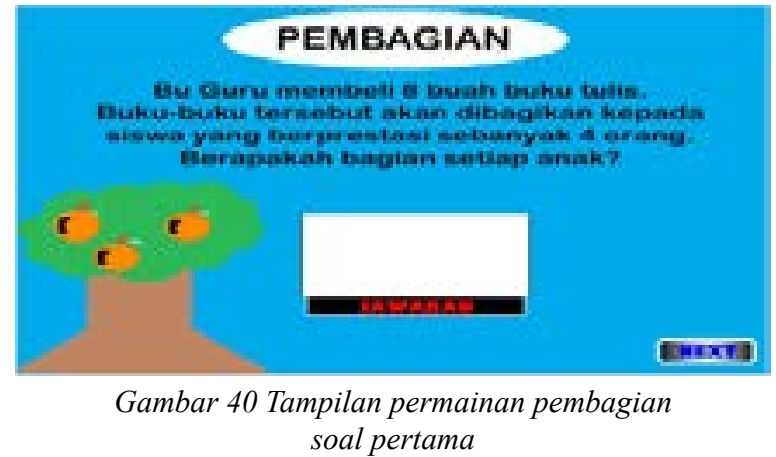

Pada Gambar 41 adalah permainan pembagian kedua yaitu permainan yang berbentuk soal essay, setelah membaca soalnya lalu masukkan angka pertama dan kedua yang ada pada soal, lalu klik tombol "=" untuk memunculkan hasilnya. Apabila sudah selesai menjawab soal yang ada, maka klik tombol next untuk ke permainan selanjutnya.

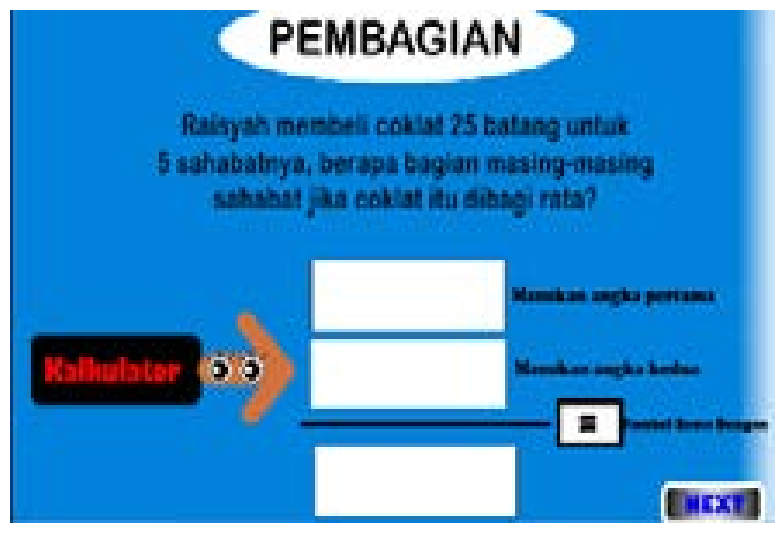

Gambar 41 Tampilan permainan pembagian soal kedua

Pada Gambar 42 adalah permainan pembagian ketiga yaitu permainan yang berkonten pilihan ganda 
dan disertai dengan adanya soal pembagian,perkalian dan pertambahan yang harus dihitung terlebih dahulu untuk menjawab soal yang ada pada angka di pot bunga. Apabila sudah selesai menjawabnya, maka akan next untuk ke halaman score.

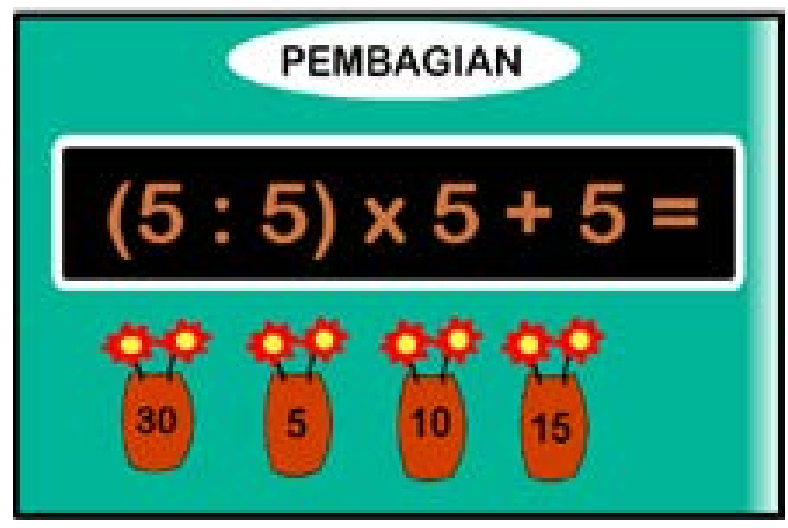

Gambar 42 Tampilan permainan pembagian soal ketiga

Pada Gambar 43 adalah tampilan total score setelah menyelesaikan permainan pembagian pertama sampai permainan pembagian ketiga. Apabila soal terjawab dengan benar semua maka mendapatkan score 100 dengan informasi "Selamat Anda Telah Menyelesaikannya..", sedangkan apabila pengguna menjawab soal dengan salah maka mendapatkan score 60, 40, 20, -40, -100 dengan informasi "Belajar Lebih Giat Lagi Ya..!". Setelah selesai melihat score nya, lalu klik tombol kembali ke menu permainan, untuk kembali ke menu permainan.

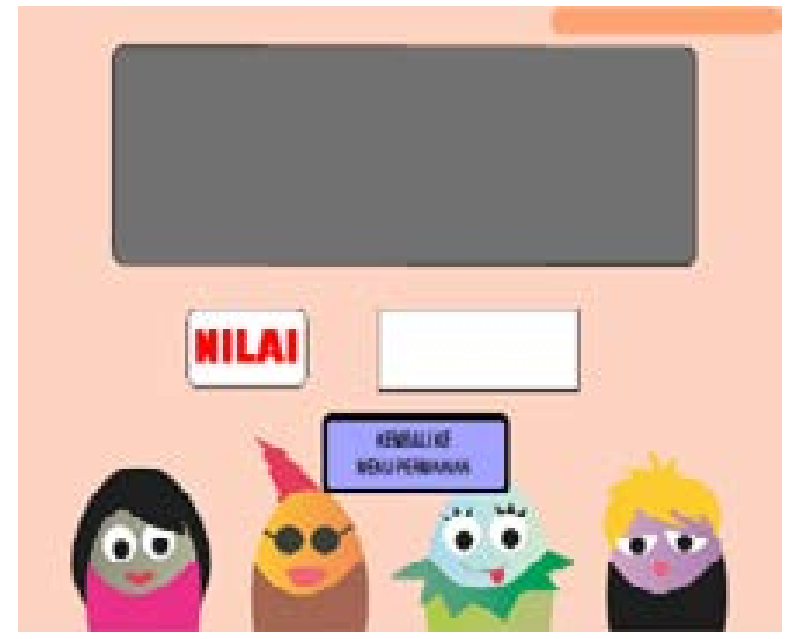

Gambar 43 Tampilan hasil akhir permainan pembagian

\section{Tampilan Menu Tes Ujian}

Pada tampilan menu tes ujian, pengguna dapat mengklik tombol lanjut untuk ke halaman berikutnya yaitu halaman cara menjawab soal pada tes ujian, apabila sudah memahami cara memainkannya, maka selanjutnya klik tombol lanjut lagi untuk memulai permainan tes ujian.

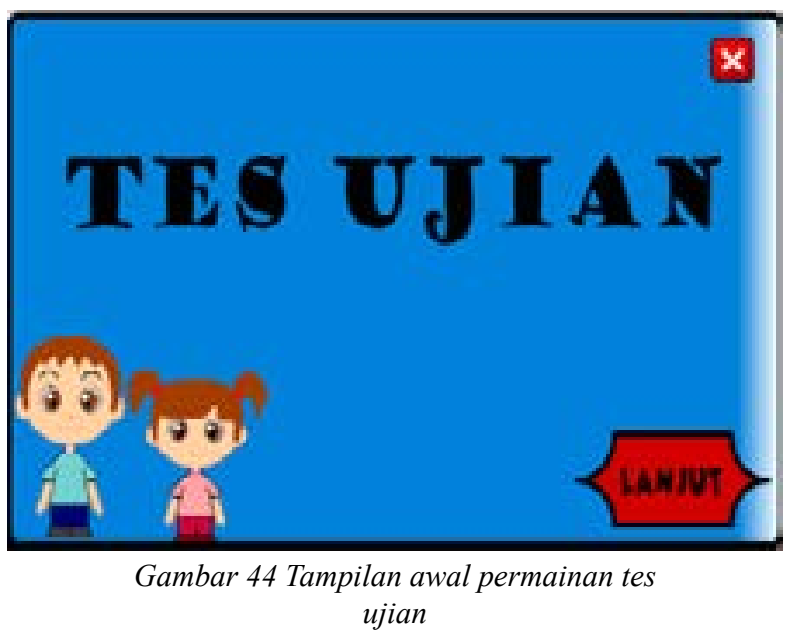

Pada Gambar 45 adalah cara menjawab soal tes ujian yaitu konten pilihan ganda dan disertai dengan adanya 10 soal cerita penjumlahan, pertambahan, pengurangan, perkalian dan pembagian yang harus dihitung terlebih dahulu untuk menjawab soal yang ada. Apabila sudah selesai memahami cara menjawab soal, maka klik tombol lanjut untuk langsung memainkannya dengan waktu 100 detik.

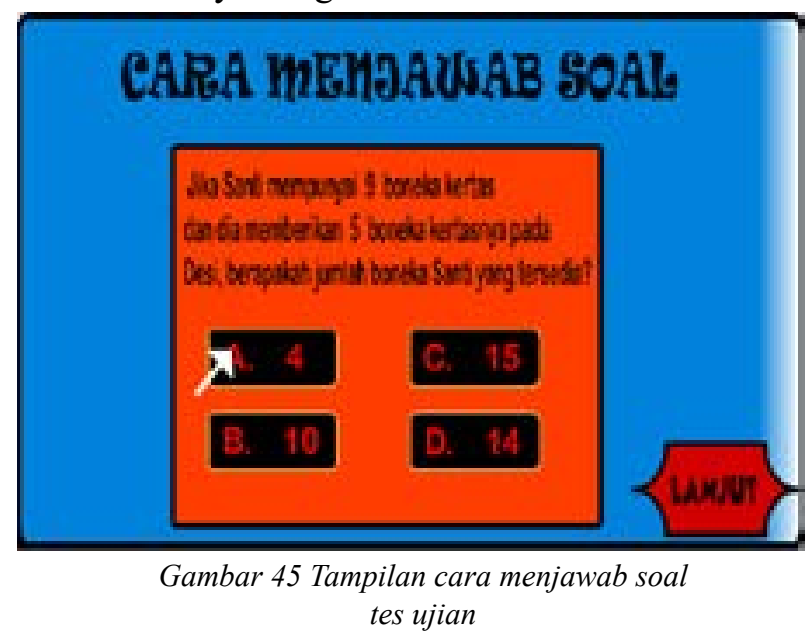

Pada Gambar 46 adalah soal penjumlahan gambar panda yang ada pada kotak. Permainan ini berkonten pilihan ganda untuk menjawabnya. Apabila sudah selesai menjawabnya, maka akan next untuk kesoal selanjutnya sampai soal ke 10, apabila soal sudah terjawab semua dan waktunya sudah abis maka akan ke tampilan total score.

Pada Gambar 47 adalah tampilan total score setelah menyelesaikan permainan tes ujian yang mempunyai 10 soal. Apabila soal terjawab dengan benar semua maka mendapatkan score 100 dengan informasi "Selamat Anda Telah Menyelesaikannya..", sedangkan apabila pengguna menjawab soal dengan salah maka mendapatkan score kurang dari $<60$ dengan informasi "Belajar Lebih Giat Lagi Ya..!". Setelah selesai melihat score nya, lalu klik tombol X untuk kembali ke menu utama. 



Gambar 47 Tampilan hasil akhir permainan tes ujian

\section{Tampilan Menu Tentan Saya}

Pada tampilan menu tentang saya, pengguna dapat melihat tampilan foto-foto murid SD Strada Van Lith II bersama kepala sekolah, peneliti. Serta terdapat sedikit profil tentang penelitinya yang

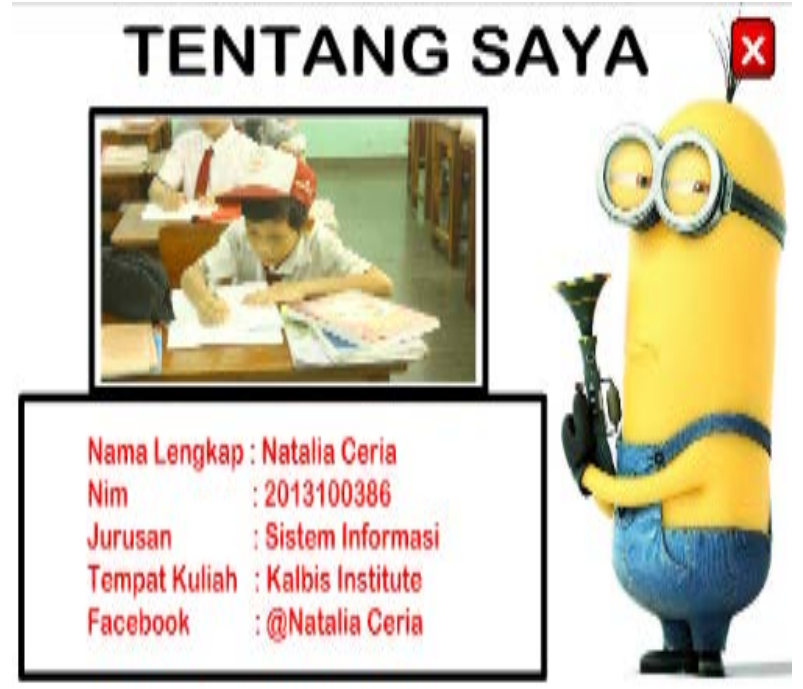

Gambar 48 Tampilan menu tentang saya dapat dilihat oleh pengguna, dan terdapat tombol exit/keluar untuk kembali kemenu utama. Tampilan halaman menu tentang saya, pada permainan edukasi operasi hitung matematika ditunjukkan pada Gambar 48 adalah tampilan menu tentang saya.

\section{E. Testing}

Pengujian merupakan bagian dari dalam siklus pembangunan perangkat lunak. Pengujian di lakukan untuk memeriksa fungsi-fungsi dalam aplikasi permainan operasi hitung matematika ini agar dapat berjalan dengan baik dan sesuai dengan perancangan yang telah di susun sebelumnya. Testing yang di lakukan oleh peneliti dengan menggunakan metode wawancara dan penyebaran kuesioner. Testing yang di lakukan untuk mengintegrasikan (menggabungkan) modul sesuai dengan hasil proses sebelumnya dalam pembuatan aplikasi. Berikut adalah skenario testing aplikasi. Gambar 8 menggambarkan skenario testing untuk navigasi utama aplikasi, sementara Gambar 9 menggambarkan skenario testing konten inti (augmented reality) aplikasi.

Berikut adalah hasil dari pengujian aplikasi berdasarkan skenario yang telah disusun pada Gambar 49 yaitu menjelaskan apakah menu atau tomboltombol yang ada pada permainan edukasi operasi hitung matematika sudah sesuai yang diinginkan dan berjalan dengan baik sehingga pada saat dijalankan atau dipresentasikan aplikasinya sesuai dengan yang diharapkan dan diterima bagi siswa-siswi SD Strada Van Lith II yang akan ditampilkan pada Gambar 50 yang menjelaskan antara lain butir uji, yang diharapkan dari aplikasi, pengamatan, dan kesimpulan dari aplikasi yang telah dibuat.

\section{F. Evaluasi Aplikasi}

Setelah aplikasi ini selesai di buat maka akan di lanjutkan ke tahap berikutnya yaitu melakukan evaluasi terhadap aplikasi. Evaluasi dilakukan untuk mengetahui ke kurangan dan kelebihan dari aplikasi permainan edukasi operasi hitung matematika dengan menggunakan penyebaran kuesioner ke kelas 1 dan siswa kelas 2 dengan jumlah murid masing-masing 15 siswa kelas 1 dan kelas 2 setelah menggunakan aplikasi. Berdasarkan hasil persentase pernyataan 1 yaitu aplikasi multimedia interaktif operasi hitung matematika dirancang dan dibuat sesuai dengan saya harapkan dan saya inginkan. Maka dapat simpulkan dari evaluasi pada kelas 1 atas sebanyak 8 responden atau 53,33\% menyatakan sangat setuju, 7 responden atau $46,67 \%$ menyatakan setuju pada pernyataan 1. Dari evaluasi pada siswa kelas 2 yaitu sebanyak 


\begin{tabular}{|c|c|c|}
\hline Keba Uy & Datrui & Laseatesi \\
\hline $\begin{array}{l}\text { Rarut nele } \\
\text { hourana }\end{array}$ & 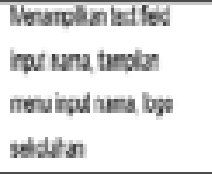 & 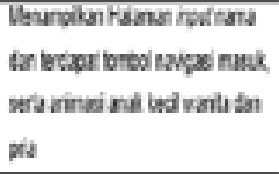 \\
\hline $\begin{array}{l}\text { RSarut nele } \\
\text { Ian }\end{array}$ & 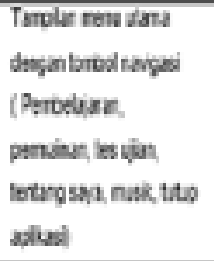 & 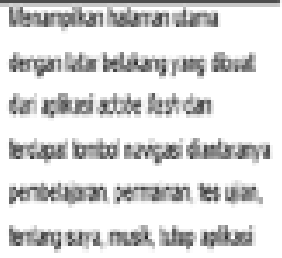 \\
\hline \multirow[t]{2}{*}{$\begin{array}{l}\text { Finut men } \\
\text { pertegirn }\end{array}$} & $\begin{array}{l}\text { Tarolar ren } \\
\text { Derveligar deron }\end{array}$ &  \\
\hline &  &  \\
\hline 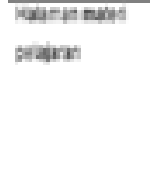 &  & 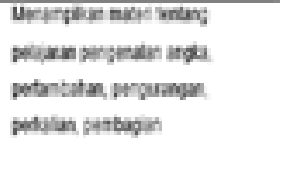 \\
\hline  & 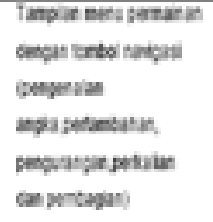 & 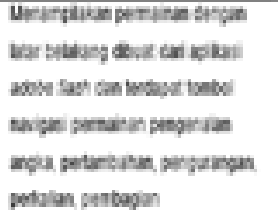 \\
\hline $\begin{array}{l}\text { Reorm } \\
\text { pernaing }\end{array}$ & 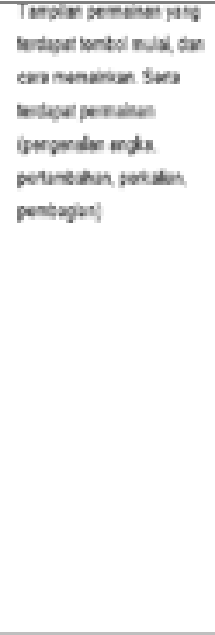 & 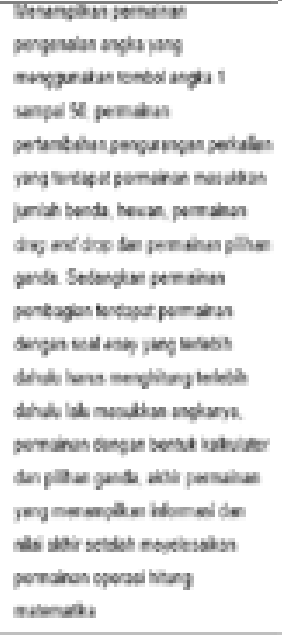 \\
\hline $\begin{array}{l}\text { Therem nom } \\
\text { let dien }\end{array}$ & 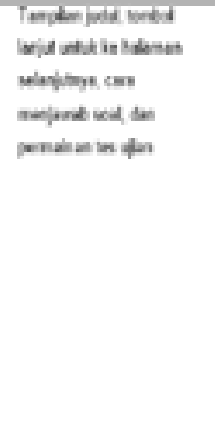 & 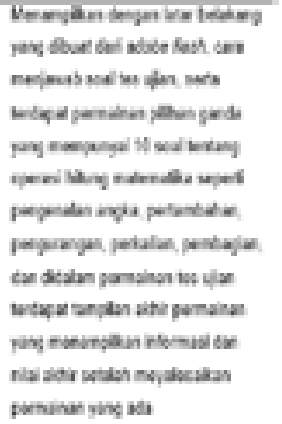 \\
\hline $\begin{array}{l}\text { Hetren latlong } \\
\text { wis }\end{array}$ & 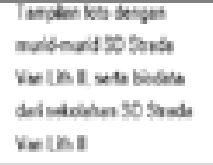 & 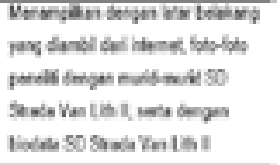 \\
\hline
\end{tabular}

Gambar 49 Skenario pengujian aplikasinavigasi utama

\begin{tabular}{|c|c|c|c|}
\hline entu & ray of ersets & fercamist & Kesingulen \\
\hline $\begin{array}{l}\text { Weans nats ick } \\
\text { tird }\end{array}$ &  & 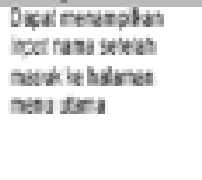 & Detra \\
\hline 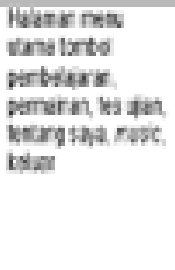 & 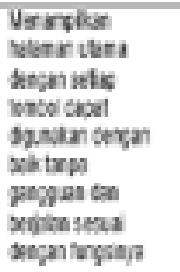 & 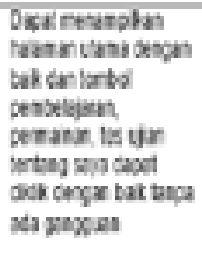 & Ourra \\
\hline 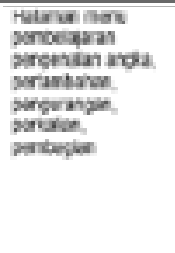 &  & 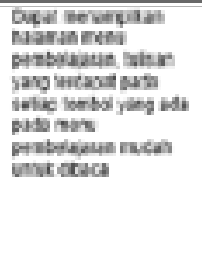 & beare \\
\hline 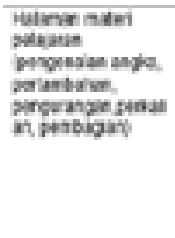 &  & 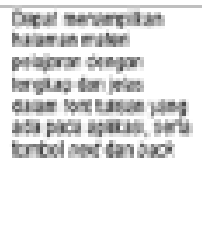 & berna \\
\hline 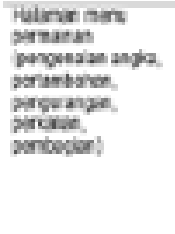 &  & 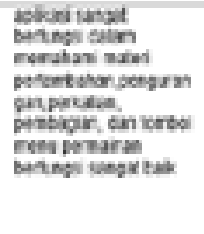 & Detrna \\
\hline 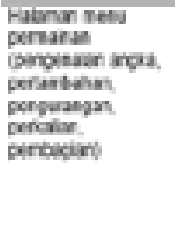 & 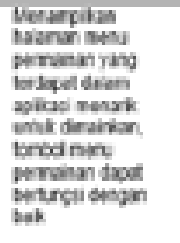 &  & Dextira \\
\hline  &  & 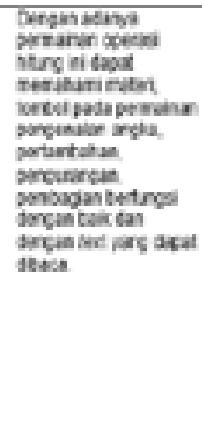 & Doveras \\
\hline $\begin{array}{l}\text { Biala an IS } \\
\text { vian }\end{array}$ &  &  & Dretins \\
\hline $\begin{array}{l}\text { Kianin ant } \\
\text { brtargata }\end{array}$ & 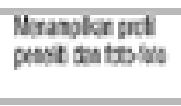 &  & Crenta \\
\hline
\end{tabular}

Gambar 50 Butir pengujian keseluruhan 
3 responden atau $20 \%$ menyatakan sangat setuju, 12 responden atau $80 \%$ menyatakan setuju pada pernyataan 1 .

Pernyataan 2 Aplikasi multimedia interaktif operasi hitung matematika mudah untuk digunakan. Maka dapat disimpulkan pada kelas 1 sebanyak 6 responden atau $40 \%$ menyatakan sangat setuju, 9 responden atau $60 \%$. Dan dari siswa kelas 2 yaitu sebanyak 7 responden atau $46,67 \%$ menyatakan sangat setuju, 8 responden atau $53,33 \%$ menyatakan setuju pada pernyataan 2 .

Pernyataan 3 yaitu materi yang disampaikan dalam aplikasi sudah lengkap dan jelas. Maka dapat disimpulkan bahwa kelas 1 sebanyak 9 responden atau $60 \%$ menyatakan sangat setuju, 3 responden atau $20 \%$ menyatakan setuju, 3 responden atau $20 \%$ menyatakan tidak setuju pada pernyataan 3. Dan dari evaluasi siswa kelas 2 yaitu sebanyak 10 responden atau $66,67 \%$ menyatakan sangat setuju, 5 responden atau 33,33\% menyatakan setuju pada pernyataan 3 . Pernyataan 4 yaitu materi yang disampaikan dalam aplikasi mudah untuk dipahami. Maka dapat disimpulkan bahwa pada siswa kelas 1 atas sebanyak 7 responden atau $46,67 \%$ menyatakan sangat setuju, 5 responden atau $33,33 \%$ menyatakan setuju, 2 responden atau $13,33 \%$ menyatakan tidak setuju, 1 responden atau $6,67 \%$ menyatakan sangat tidak setuju pada pernyataan 4. Dan dari evaluasi pada siswa kelas 2 sebanyak 4 responden atau $26,66 \%$ menyatakan sangat setuju, 10 responden atau $66,67 \%$ menyatakan setuju, 1 responden atau $6,67 \%$ menyatakan tidak setuju pada pernyataan 4. Pernyataan 5 materi yang disampaikan dalam aplikasi disajikan dengan menarik dan kreatif. Maka dapat disimpulkan bahwa pada siswa kelas 1 atas sebanyak 6 responden atau $40 \%$ menyatakan sangat setuju, 7 responden atau $46,67 \%$ menyatakan setuju, 1 responden atau $6,67 \%$ menyatakan tidak setuju, 1 responden atau $6,67 \%$ menyatakan sangat tidak setuju pada pernyataan 5. Dan dari siswa kelas 2 sebanyak 3 responden atau 20\% menyatakan sangat setuju, 10 responden atau $66,67 \%$ menyatakan setuju, 2 responden atau $13,33 \%$ menyatakan tidak setuju pada pernyataan 5. Pernyataan 6 setiap tombol yang terdapat dalam aplikasi dapat digunakan dengan baik tanpa gangguan dan berjalan sesuai dengan fungsinya. Maka dapat disimpulkan bahwa pada siswa kelas 1 atas sebanyak 5 responden atau 33,33\% menyatakan sangat setuju, 8 responden atau 53,33\% menyatakan setuju, 2 responden atau 13,33\% menyatakan tidak setuju pada

Pernyataan 6. Dan dari siswa kelas 2 sebanyak 6 responden atau $40 \%$ menyatakan sangat setuju,
9 responden atau 60\% menyatakan setuju pada pernyataan 6. Pernyataan 7 yaitu tulisan yang terdapat pada setiap tombol dalam aplikasi mudah untuk dibaca. Maka dapat disimpulkan bahwa pada siswa kelas 1 atas sebanyak 9 responden atau $60 \%$ menyatakan sangat setuju, 6 responden atau $40 \%$ menyatakan setuju pada pernyataan 7. Dan dari siswa kelas 2 sebanyak 5 responden atau 33,33\% menyatakan sangat setuju, 10 responden atau $66,67 \%$ menyatakan setuju pada pernyataan 7 .

Pernyataan 8 yaitu karakter animasi atau kertun yang terdapat pada beberapa halaman dalam aplikasi menarik untuk dilihat. Maka dapat disimpulkan bahwa pada siswa kelas 1 atas sebanyak 8 responden atau 53,33\% menyatakan sangat setuju, 6 responden atau $40 \%$ menyatakan setuju, 1 responden atau $6,67 \%$ menyatakan tidak setuju pada pernyataan 8 . Dan dari siswa kelas 2 sebanyak 4 responden atau $26,66 \%$ menyatakan sangat setuju, 10 responden atau $66,67 \%$ menyatakan setuju, 1 responden atau $6,67 \%$ menyatakan tidak setuju pada pernyataan 8 .

Pernyataan 9 yaitu tulisan yang terdapat dalam aplikasi mudah untuk dibaca dan dipahami. Maka dapat disimpulkan bahwa pada siswa kelas 1 atas sebanyak 11 responden atau $73,33 \%$ menyatakan sangat setuju, 4 responden atau $26,67 \%$ menyatakan setuju pada pernyataan 9. Dan dari evaluasi pada siswa kelas 2 sebanyak 6 responden atau $40 \%$ menyatakan sangat setuju, 8 responden atau $53,33 \%$ menyatakan setuju, 1 responden atau $6,67 \%$ menyatakan tidak setuju pada pernyataan 9 .

Pernyataan 10 yaitu gambar-gambar yang digunakan dalam aplikasi sesuai dengan tema pembahasan aplikasi yaitu operasi hitung matematika. Maka dapat disimpulkan bahwa pada siswa kelas 1 atas sebanyak 4 responden atau $26,67 \%$ menyatakan sangat setuju, 11 responden atau $73,33 \%$ menyatakan setuju pada pernyataan 10. Dan dari siswa kelas 2 sebanyak 5 responden atau 33,33\% menyatakan sangat setuju, 9 responden atau $60 \%$ menyatakan setuju, 1 responden atau $6,67 \%$ menyatakan tidak setuju pada pernyataan 10 .

\section{SIMPULAN}

Berdasarkan hasil keseluruhan peneliti, maka dapat di ketahui bahwa hasil akhir penelitian adalah aplikasi Permainan Edukasi Operasi Hitung Matematika berbasis multimedia yang memberikan informasi dapat disimpulkan bahwa materi yang ada pada permainan yaitu pengenalan angka,pertambahan, pengurangan, perkalian, pembagian, dengan adanya unsur multimedia dalam aplikasi pembelajaran ini 
membuat siswa kelas 1 dan kelas 2 SD Strada Van Lith II tertarik dalam mempelajari matematika, aplikasi permainan operasi hitung matematika berbentuk compact disk (CD) interaktif dengan ukuran file $302.245 \mathrm{~KB}$

\section{DAFTAR RUJUKAN}

[1] H. Darmadi. Pengembangan Model Metode Pembelajaran dalam Dinamika Belajar Siswa. Yogyakarta: Hak Cipta, 2017. hlm. 78-89

[2] W. N. Putri. "Pengaruh Media Pembelajaran Terhadap Aktivitas Siswa". Journal of Arabic Education and
Literature. Vol 1, No.1, 2017. hlm 39-40.

[3] J. Wijanarko \& E. Setiawati. Ayah Baik- Ibu Baik Parenting Era Digital. Jakarta: Keluarga Indonesia bahagia bumi Bintaro permai, 2016. hlm. 8-29.

[4] A. H. Sutopo. Teknologi Informasi dan Komunikasi dalam Pendidikan. Yogyakarta: Graha Ilmu, 2012. hlm.131-134, 135-136.

[5] L. Sitorus. Algoritma dan Pemrograman. Yogyakarta: CV ANDI OFFSET, 2015. hlm. 14-16, 3-4, 5.

[6] A. H. Sutopo. Multimedia Interaktif Dengan Flash. Yogyakarta: Graha Ilmu, 2003.hlm. 32-48, 3-6. 
Kalbiscentia, Jurnal Sains dan Teknologi, Volume 7, No. 1, Februari 2020 
Kalbiscentia, Jurnal Sains dan Teknologi, Volume 7, No. 1, Februari 2020 
